\title{
Siting Renewable Energy: Land Use and Regulatory Context
}

\author{
Uma Outka*
}

This Article takes up the increasingly important land use question of siting for renewable energy. As concern over climate change grows, new policies are being crafted at all levels of government to support renewable energy as a way of reducing greenhouse gas emissions. These policies are driving the need to site and construct new power plants that will utilize renewable resources. Historically, power plant siting has been the province of state and local governments, so the regulatory context into which renewables are being integrated varies, sometimes significantly, jurisdiction by jurisdiction.

To examine this regulatory context, this Article focuses on Florida, a state which consumes the third-most electricity in the United States but which generates less than 2 percent of that electricity from renewable resources. The Article first provides an overview of Florida's power supply sector and sets out the existing regulatory context for terrestrial siting of energy facilities. It then situates Florida's most promising renewable resources within that context, identifies regulatory barriers that implicate siting, and considers the siting issues unique to each resource. As the article explains, we now have a window of opportunity in which state and local governments can plan for and guide renewable energy siting-an approach that contrasts with utility-driven planning and siting that has long been standard practice.

\footnotetext{
Copyright $\odot 2010$ by the Regents of the University of California.

Visiting Scholar in Energy and Land Use Law, Florida State University College of Law; faculty member, Florida State University's Institute for Energy Systems, Economics, and Sustainability (IESES). A special thanks is due to IESES for supporting this work. I am also grateful to Robin Craig, David Markell, Dan Markel, Jim Rossi, and J.B. Ruhl, as well as Richard Grosso, Jason Totiou, and Paul Outka, for their thoughtful advice and comments on early drafts. Additionally, Mike Halpin, Mark Siedenfeld, Lynn Holt, Susan Glickman, Julie Wraithmell, Charles Pattison, Jay Liles, Barry Moline, Vinette Godelia, Gary Sams, and Bill Hyde all shared their perspectives on a range of issues considered in the piece. Andrew Fier provided research assistance. Errors are my own. Please direct comments or questions to uoutka@law.fsu.edu.
} 


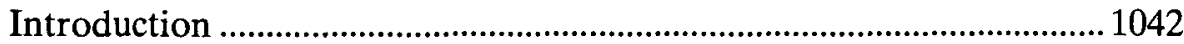

I. Overview of Power Production and Consumption in Florida.... 1048

A. Existing Power Generation ..................................................1050

B. Renewable Energy Potential................................................... 1052

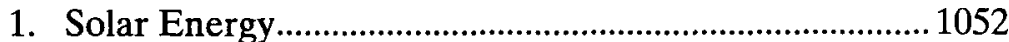

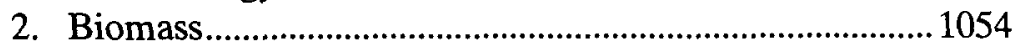

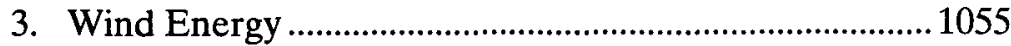

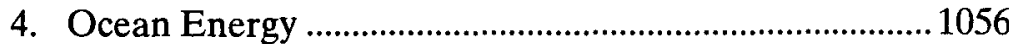

II. Existing Legal Framework for Siting Energy Facilities............... 1057

A. Energy Infrastructure Planning in Florida............................. 1058

B. The Electrical Power Plant Siting Act ....................................1060

C. The Growth Management Act.................................................. 1064

III. Siting Context for Renewable Energy Resources........................ 1067

A. Siting Solar Energy .................................................................1069

1. Ground-Mounted Photovoltaic Arrays ............................ 1070

a. Regulatory Context.....................................................1070

b. Other Siting Considerations........................................1073

2. Rooftop Photovoltaic Panels................................................ 1077

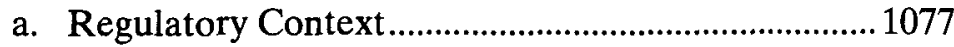

b. Other Siting Considerations..........................................1081

B. Siting Biomass.......................................................................... 1086

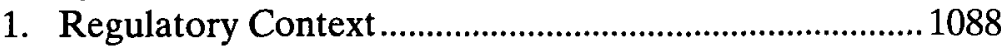

2. Other Siting Considerations ...............................................1091

IV. Opportunities to Guide Renewable Energy Siting .....................1096

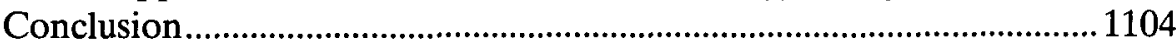

\section{INTRODUCTION}

Across the nation, electrical power is supplied overwhelmingly by burning fossil fuels. This is starting to change-as concern over climate change grows, new policies are being crafted at all levels of government to support renewable energy as a way of reducing greenhouse gas emissions. These policies are driving the need to site and construct new power plants that will utilize renewable resources. As interest in renewable energy grows, however, questions arise. How do existing legal frameworks for siting power plants accommodate renewable energy facilities? Are the same siting considerations at play, or are there others, unique to specific renewable resources or technologies?

This article takes up this increasingly important land use question of siting for renewable energy. Historically, power plant siting has been the province of state and local governments, so the regulatory context into which renewables are being integrated varies, sometimes significantly, jurisdiction by jurisdiction. The article examines this regulatory context with a focus on Florida, the third largest consumer of electricity in the 
United States, but with less than 2 percent of its electricity generated by renewable resources.

The effort to advance renewable energy in Florida has been building slowly over the last several years. The Florida Legislature declared in 2005 that "it is in the public interest to promote the development of renewable energy resources in this state." In 2006, the Legislature passed the Florida Energy Act, creating the Florida Energy Commission (FEC), renewable energy grants, and a solar rebate program, among other things, and in 2007, Governor Charlie Crist signed a series of executive orders aimed at reducing greenhouse gas emissions and establishing an Action Team on Energy and Climate Change. ${ }^{2}$ The Legislature passed an energy bill in 2008 calling on the Public Service Commission to develop a renewable portfolio standard (RPS), a mechanism employed in many states to ensure that a fixed percentage of electricity is generated from renewable resources. ${ }^{3}$ The Action Team released Florida's Energy and Climate Change Action Plan, concluding, among other things, that "now is the time for strategic investment in Florida's low-carbon energy infrastructure." 4

A range of regulatory approaches could facilitate a pronounced increase in power generation from renewable sources in Florida. ${ }^{5}$ Although the Legislature failed to ratify the RPS during the 2009

1. FLA. STAT. § 366.91(1) (2009).

2. See 2006 Fla. Laws ch. 230 (S.B. 888); Exec. Order No. 07-126, Leadership by Example: Immediate Actions to Reduce Greenhouse Gas Emissions from Florida State Government (July 13, 2007); Exec. Order No. 07-127, Immediate Actions to Reduce Greenhouse Gas Emissions within Florida (July 13, 2007); Exec. Order No. 07-128, Florida Governor's Action Team on Energy and Climate Change (July 13, 2007).

3. See 2008 Fla. Laws ch. 227 (H.B. 7135).

4. Center for Climate Strategies, Florida's Energy and Climate Change ACTION PLAN 11 (2008) [hereinafter ACTION PLAN], available at http://www. flclimatechange.us/documents.cfm (last visited Oct. 16, 2010) (referencing both renewable and nuclear energy). This opening highlights a few key policy events in recent years, but is by no means a summary of the range of regulations now in effect with respect to renewable energy. For more, see, e.g., Florida Incentives/Policies for Renewables and Efficiency, DATABASE OF STATE INCENTIVES FOR RENEWABLE ENERGY, http://www.dsireusa.org/ incentives/index.cfm?re=1\&ee $=1 \& \mathrm{spv}=0 \& \mathrm{st}=0 \& \mathrm{srp}=1 \&$ state $=\mathrm{FL}$ (last visited Oct. 10, 2010).

5. The Governor's Action Team recommended fifty policy actions to structure the state's response to climate change, including twenty-two dealing specifically with energy supply and demand. See ACTION PLAN, supra note 4, app. A. For overviews of the range of policies being implemented across the country, see U.S. ENVTL. Prot. AgENCY, ClEan EnERgyEnvironment Guide to ACtion: Policies, Best Practices, and ACtion Steps for STATES (2006), and the more recent ElIZABETH DORIS ET AL., NAT'L RENEWABle ENERGY LABORATORY, STATE OF THE STATES 2009: RENEWABLE ENERGy DEVELOPMENT AND THE ROLE OF POLICY 74 (2009). For a searchable online inventory of state renewable energy policies and incentives, see DATABASE OF STATE INCENTIVES FOR RENEWABLE ENERGY [hereinafter DSIRE], http://www.dsireusa.org (last visited Oct. 10, 2010). 
legislative session, the measure remains under consideration. ${ }^{6}$ The RPS, as originally drafted, would have required 20 percent of the state's energy supply to be derived from renewable resources. Of course, this and other policies may still come into effect through federal legislation, or at the state level in future sessions. At this juncture, states have many policy options to encourage renewable energy. ' Yet, as the National Commission on Energy Policy recently observed, "energy-facility siting and permitting remains a major cross-cutting challenge for U.S. energy policy." This challenge arises from a variety of factors: "[e]nvironmental concerns, federal-state regulatory conflicts, aesthetic preferences, highly localized planning processes, investment risks and preferences and regional policy differences," to name a few. ${ }^{9}$ Ultimately, the context for siting is always local, but as component parts of a national effort to mitigate climate change, "local siting decisions frequently have national implications." 10

Even absent an RPS or other policy to accelerate resource development, siting is vitally important in at least two respects. First, renewable energy facilities are already being sited and constructed, though less often in Florida than would be the case with an RPS in effect. Second, and perhaps more important, if either the federal government or Florida alone adopts an RPS, ${ }^{11}$ there will be new pressure to develop renewable energy facilities, rapidly bringing siting decisions and controversies to communities around the state. Analysis of recurring siting issues when there is still time to plan can help determine how best to incorporate renewable energy into the Florida landscape. Whether or not an RPS passes, in other words, we can expect the number of renewable energy facilities across the state to increase.

6. See S.B. 774, 112th Leg. (Fla. 2010); S.B. 596, 112th Leg. (Fla. 2010). Florida is one of only 15 states that have not adopted an RPS or similar measure. See DORIS ET AL., supra note 5, at 74; see also DSIRE, supra note 5.

7. There are, of course, non-regulatory factors affecting renewable energy development in the United States. See, e.g., ACTION PLAN, supra note 4, at 3-9 (citing "price distortions, failure of the market to value the public benefits of renewables, and the social cost of fossil fuel technologies, inadequate information, institutional barriers to grid interconnection, high transaction costs due to small project size, high financing costs because of lender unfamiliarity, and perceived risk"); DORIS, ET AL., supra note 5, at 121-134 (similar list).

8. NAT'L COMM'N ON ENERGY POL'Y, SITING CRITICAL ENERGY INFRASTRUCTURE: AN OVERVIEW OF NEEDS AND CHALLENGES 1 (2006).

9. Id.

10. Id. at 4 .

11. Although the RPS model has been utilized in many states, some argue that the feed-in tariff model would be more effective. I cite RPS simply because Florida has considered an RPS developed by the Public Service Commission and has not yet considered a feed-in-tariff policy at the state level. See Renewable Portfolio Standard Rule (proposed Jan. 30, 2009), available at http://www.psc.state.fl.us/utilities/electricgas/RenewableEnergy/2009_FPSC_Draft_RPS_Rule.p df. 
This article proceeds from several basic premises. First, the article supports the general premise that renewable energy should be promoted, supported, and advanced in Florida and across the nation. It does not, however, presume that all forms of renewable energy should be treated alike, from either a policy or a siting standpoint. How "renewable energy" is defined has genuine implications for how and whether it should be promoted categorically.$^{12}$ The article attempts to untangle some of these questions insofar as they touch upon siting.

Second, from an environmental standpoint, the foremost siting imperative should be to avoid the need for new facilities through energy efficiency and conservation. Power plant siting in Florida depends on assumptions about Florida's future demand for electricity, but these estimates are not fixed. ${ }^{13}$ How much future demand can and should be offset through efficiency measures is an essential and hotly contested question. ${ }^{14}$ The American Council for an Energy-Efficient Economy projects that "[e]nergy efficiency resource policies can offset the majority of projected load growth in [Florida] over the next fifteen years . . . deferring the need for many new electric power generation projects in the state." ${ }^{15}$ Similarly, researchers who analyzed recent efficiency studies found consistency among the data showing "a reservoir of cost-effective energy savings" and strategies in Florida that, if fully deployed, could "largely offset the growth in energy consumption forecasted for the region over the next decade," while "reduc[ing] capacity-related costs associated with . . . energy natural gas infrastructure expansion and supply." ${ }^{16}$ Florida can and should pursue energy efficiency aggressively in

12. Recent Florida legislative sessions have underscored the importance and implications of how "renewable energy" is defined, with competing bills differing with regard to whether "renewable" portfolio standard should be termed "clean" portfolio standard to allow for the addition of nuclear energy. See, e.g., S.B. 774, 112th Leg. (Fla. 2010) (to create "renewable" portfolio standard); S.B. 596, 112th Leg. (Fla. 2010) (to create "clean" portfolio standard including nuclear energy).

13. In their 2009 Ten-Year Site Plans, Florida electric utilities planned to add a net summer capacity of approximately $11,000 \mathrm{MW}$ over the next 10 years - a figure that represents a decrease of approximately $4500 \mathrm{MW}$ compared to the 2008 plans and projections. See FLA. PUB. SERV.

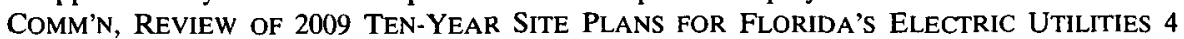
(2009).

14. Every five years, the Florida Energy Efficiency and Conservation Act requires the Public Service Commission to set numeric energy conservation goals for regulated utilities. In 2009 , a goal-setting year, the commission applied 2008 amendments to the statute that require the goals to be based on "the full technical potential of all available demand-side and supply-side conservation and efficiency measures, including demand-side renewable energy systems." FLA. STAT. \$ 366.82(3) (2009); see Commission Review of Numeric Conservation Goals, 2009 Fla. PUC LEXIS 1100 (Fla. P.S.C. 2009).

15. R. NEAl ElliotT ET AL., AM. COUNCIL FOR AN ENERGY-EFFICIENT ECON., REPORT No. E072, POTENTIAL FOR ENERGY EFFICIENCY AND RENEWABLE ENERGY TO MEeT FLORIDA'S GROWING ENERGY DEMANDS iv, 39 (2007).

16. Sharon Chandler \& Marilyn A. Brown, Meta-Review of Efficiency Potential Studies and Their Implications for the South 2 (Georgia Tech Ivan Walker Allen College School of Public 
multiple directions-building codes, for example, are key-but utilitysector efficiency is arguably the most important. ${ }^{17}$

The potential for efficiency to offset demand growth underscores the land use implications of energy inefficiency. Building a new energy facility is never environmentally neutral, as even a non-polluting resource like solar energy comes with negative environmental impacts associated with component manufacturing and construction. ${ }^{18} \mathrm{~A}$ new facility avoided can mean a local community not burdened with unnecessary environmental impacts, or a natural site left pristine.

The scope of this article is limited to siting renewable energy for electricity generation. ${ }^{19}$ Likewise, siting for nuclear energy is not discussed, for several reasons. First, although nuclear energy is recognized as a "low-carbon" resource, it is consistently distinguished from "renewable" energy sources under federal and Florida law."

Policy, Working Paper No. 51, 2009), available at http://www.spp.gatech.edu/faculty/ workingpapers/wp51.pdf; see also JOHN FARRELL \& DAVID MORRIS, THE NEW RULES PROJECT, ENERGY SELF-RELIANT STATES, SECOND AND EXPANDED EDITION 20 (2009) (finding that "most states could achieve absolute reductions [in electricity consumption] in the short term if they approached the electricity efficiency of California").

17. See ELLIOTT ET AL., supra note 15 , at 17 . Florida has made notable strides in this area. See, e.g., FLA. STAT. $\$ 553.9061$ (2009) (scheduled increase in thermal efficiency standards for buildings). For an assessment of Florida's energy code and recommendations for improvements, see Fla. SOLAR ENERGY CTR., FSEC-CR-1806-09, EFFECTIVENESS OF FLORIDA'S RESIDENTIAL ENERGY CODE: 1979-2009, (2009).

18. See, e.g., Silicon VAlley TOXICS COAlition, TOWARd a Just AND Sustainable SOLAR ENERGY INDUSTRY (2009), available at http://www.svtc.org/site/PageServer?pagename =svtc_publications (last visited Oct. 10, 2010) (detailing pollution impacts of solar panel manufacture and disposal).

19. This limitation is to the exclusion of biofuels and solar thermal collectors producing heat for hot water, both of which rely on renewable energy resources for other purposes. For a general overview of infrastructure siting for biofuels, see NAT'L COMM'N ON ENERGY POL'Y, supra note 8, at 38-41. For an overview and analysis of the most prominent U.S. biofuels and biomass policies to date, their interactions, and import to the electricity, transportation, and agriculture sectors, see JOSHUA BLONZ ET AL., RES. FOR THE FUTURE, DISCUSSION PAPER 0847, Growing COMPLEXITIES: A CROSS-SECTOR REVIEW OF U.S. BIOFUELS POLICIES AND THEIR INTERACTIONS 2 (2008).

20. This distinction persists in spite of rebranding efforts of the nuclear energy industry. See, e.g., James Kanter, Is Nuclear Power Renewable?, N.Y. Times GreEN BLOG (Aug. 3, 2009, 9:27 AM), http://green.blogs.nytimes.com/2009/08/03/is-nuclear-power-renewable (discussing industry efforts and motivations to rebrand, and noting that "so far, efforts to categorize nuclear as a renewable source of power are making little headway"); Keith Johnson, Is Nuclear Power Renewable Energy? WALL ST. J. ENVTL. CAPITAL (May 21, 2009, 3:26 PM), http://blogs.wsj.com/environmentalcapital/2009/05/21/is-nuclear-power-renewable-energy (similar general commentary). For a discussion of Florida's definition of "renewable energy," see supra note 12; infra Part 11.B. See also Energy Policy Act of 2005, 42 U.S.C. $\$ 15852$ (2006) ("The term "renewable energy" means electric energy generated from solar, wind, biomass, landfill gas, ocean (including tidal, wave, current, and thermal), geothermal, municipal solid waste, or new hydroelectric generation capacity achieved from increased efficiency or additions of new capacity at an existing hydroelectric project."); Nuclear Explained; Where Our Uranium Comes From, U.S. ENERGY INFO. ADMIN., http://www.eia.doe.gov/energyexplained/ 
Second, policies to advance renewable energy and nuclear power are frequently conjoined, but not always, ${ }^{21}$ and the two industries accordingly compete for policy precedence and governmental subsidies. ${ }^{22}$ Third, nuclear facilities are subject to extensive federal regulation, from siting to decommissioning, that does not apply to renewable resources. ${ }^{23}$ Thus, although nuclear and renewable energy may be compatible sources of low-carbon power in the face of climate constraints, the differing regulatory and policy contexts for each warrants separate examination.

Finally, the Article does not take up siting for transmission infrastructure. Transmission expansion is an issue of national importance that gives rise to significant siting challenges..$^{24}$ In some areas of the country, the shift to renewable energy is playing a part in creating the need for new transmission lines. ${ }^{25}$ In Florida, however, although new

index.cfm?page=nuclear_where (stating that "uranium is nonrenewable" and most of the kind of uranium required for nuclear plants is imported) (last visited Oct. 10, 2010).

21. Unresolved debate continues over public health and environmental impacts of radioactive waste disposal from nuclear power, and security risks associated with importing needed uranium and nuclear proliferation. See, e.g., ACTION PLAN, supra note 4, app. A at 28 (highlighting "significant potential risks associated with nuclear power, including unresolved waste disposal issues, negative impacts on human health, cost overruns, and siting and permitting issues that must be considered"); see also Richard B. Stewart, U.S. Nuclear Waste Law and Policy: Fixing a Bankrupt System, 17 N.Y.U. ENVTL. L.J. 783 (2008) (describing flaws in nuclear waste disposal policy); Amory Lovins, Proliferation, Oil, and Climate: Solving for Pattern, ROCKY MOUNTAIN INST., http:/www.rmi.org/rmi/Library/201002_ProliferationOilClimate Pattern (last visited Oct. 10, 2010) (arguing against increased reliance on nuclear power based on risk of proliferation). But $c f$. U.S. DEP'T OF ENERGY, http://www.energy.gov/ energysouces/index.htm (last visited Oct. 10, 2010) (discussing programs promoting renewable and nuclear energy as distinct but compatible); INT'L NUCLEAR \& RENEWABLE ENERGY CONFERENCE, http://www.inrec10.inrec-conf.org (last visited Oct. 10, 2010) (addressing "the first of a planned series of biennial meetings focusing on the practical aspects of carbon-free energy forms (nuclear and renewables)").

22. See generally U.S. ENERGY INFO. ADMIN., FEDERAL FINANCIAL INTERVENTIONS AND SUBSIDIES OF ENERGY MARKETS 2007 xi-xiii (2008), available at http:/www.eia. doe.gov/oiaf/servicerpt/subsidy2/df/execsum.pdf (comparing subsidies allotted in support of competing energy industries but noting that although "[s]ome of the most significant subsidy provisions in EPACT2005 concern nuclear power . . . the report provides no estimates for the value of these provisions" because "no new nuclear power plants are expected to produce electricity before the middle of the decade"). Within the "renewable energy industry," of course, there can be competition between proponents of particular resources, but typically from within the same pool of allocated benefits for "renewable energy," distinct from nuclear.

23. For summary and detailed information about federal regulation of nuclear power plants, see U.S. NUCLEAR REGULATORY COMMISSION, http://www.nrc.gov (last visited Oct. 10, 2010).

24. See NAT'L COMM'N ON ENERGY POL'Y, supra note 8, at 16 (noting the "consensus among transmission system users . . . that substantial investments in new transmission lines and related equipment are needed to maintain the reliability and operational requirements of the system, meet growth in demand and in transactions, and to ensure a robust wholesale market for power").

25. See generally AM. WIND ENERGY ASS'N \& SOLAR ENERGY INDUS. ASS'N, GREEN POWER SUPERHIGHWAYS: BUILDING A PATH TO AMERICA'S CLEAN ENERGY FUTURE (2009), available at http://www.awaea.org/GreenPOwerSuperhighways.pdf (last visited Oct. 10, 2010). In 
transmission lines have been proposed and sited in the state, there is no immediate need for increased transmission line siting as a result of renewable energy development. ${ }^{26}$ This will change when and if offshore ocean or wind energy facilities are proposed, but these resources are at least several years away from commercialization off Florida's coasts. ${ }^{27}$

Part I provides both a general overview of Florida electricity production and consumption and a brief summary of the renewable resources considered viable in Florida. Part II lays out the existing legal framework for siting energy facilities in the state. Part III takes up Florida's most promising near-term renewable resources-solar energy and biomass-considering each in the larger siting context. Part IV argues that a window of opportunity exists to guide renewable energy siting and offers a range of potential approaches at the state and local level.

\section{OVERVIEW OF POWER PRODUCTION AND CONSUMPTION IN FLORIDA}

In shared concern over climate change, policymakers in Florida and nationwide are grappling with how to reduce greenhouse gas (GHG) emissions generated within their borders. ${ }^{28}$ The energy supply sector has

response to this need, some Western states have even established offices or agencies specifically to address transmission for renewable energy. See, e.g., NEW MEXICO RENEWABLE ENERGY TRANSMISSION AUTHORITY, http://www.nmreta.org (last visited Oct. 10, 2010); CALIFORNIA'S RENEWABLE ENERGY TRANSMISSION INITIATIVE, http://www.energy.ca.gov/reti (last visited Oct. 10, 2010).

26. As a peninsular state, Florida is also subject to unique complexities beyond the scope of this Article. For information on Florida's present transmission infrastructure capacity and planned expansions, see Fla. PUB. SERV. COMM'N., REVIEW OF 2009 TEN-YEAR SitTe PlanS FOR FLORIDA'S ELECTRIC UTILITIES 32-35 (2009) (listing new transmission lines proposed and in development, and noting that transfer capacity between Florida and the Southern grid to the north is not limited by reliability constraints at this time). With an RPS or other policies in place to stimulate renewable energy development, however, transmission expansion could become a more pressing issue. A recent report on energy siting by Resources for the Future asserts that "development of both intra-state and inter-state transmission capacity is a necessary prerequisite for any considerable renewable energy penetration into the market in coming years" and analyzes transmission siting difficulty by state. SHAHINI VAJHALA, RES. FOR THE FUTURE, DISCUSSION PAPER 06-34, SITING RENEWABLE ENERGY FACILITIES: A SPATIAL ANALYSIS OF PROMISES AND PITFALLS 7.6 (2006). The spatial analysis determined Florida to be above average in difficulty and below average in demand for expansion. See id. at 8 . The author predicts that "difficulty associated with siting transmission lines provides an important litmus test of the potential difficulty facing new renewable energy development" and specifically an "indicator of potential siting problems facing new renewable energy facilities." Id. at 7-8; see also S.P. Vajjhala \& P.S. Fischbeck, Quantifying Siting Difficulty: A Case Study of U.S. Transmission Line Siting, 35 ENERGY POL'Y, 650 (2007).

27. See discussion infra Part II.B.

28. For an overview of existing and projected climate change impacts, see generally U.S. global Change Research Program, Global Climate Change impacts in the UNITED STATES (2009), available at http://www.globalchange.gov/usimpacts (last visited Oct. 10, 
the distinction of being both the most significant source of GHG emissions $^{29}$ as well as the sector in which emissions have risen most sharply in recent years. ${ }^{30}$ Between 1970 and 2004, a period marked by a dramatic upward trajectory for GHG emissions worldwide from all sources, emissions from electricity generation increased 145 percent. ${ }^{31}$

In Florida, which consumes more electricity than almost any other state ${ }^{32}$ power production and consumption is responsible for 53 percent of Florida's GHG emissions. ${ }^{33}$ Fortunately, from the standpoint of emissions reductions, the energy sector also has the greatest potential for improvement. ${ }^{34}$ Reducing the use of fossil fuels and shifting toward renewable energy production are key reforms with broad-based support. Debate continues over how significant the role for renewable energy can or should be, but movement in this direction is occurring in every state and at the federal level. Over twenty-five states have adopted renewable portfolio standards ${ }^{35}$ forty-nine have grants or other financial incentives for renewable energy, ${ }^{36}$ and hundreds of millions of federal dollars are being funneled to renewable energy projects and research nationwide. ${ }^{37}$

Although Florida has yet to jumpstart its own renewable energy market, many in and outside of government have been working to that end. In considering measures to reduce emissions from the energy supply sector, the Governor's Climate Action Team identified the three most promising policy approaches to be promoting renewable energy, power

2010); see also ACTION PLAN, supra note 4, at 31-39 (discussing link between GHG and climate change).

29. See ACtIOn Plan, supra note 4, at 14 (showing electricity consumption to be largest source of GHG emissions nationwide and in Florida).

30. See Governor's action team on Energy and Climate Change, Phase 1 REPORT: Florida's ENERGY AND ClimATE ChANGE ACTION Plan 8 (2007), available at http://www.flclimatechange.us/documents.cfm (last visited Oct. 10, 2010). For a discussion of climate change impacts nationally, see U.S. Global Change Research Program, supra note 28.

31. See id.

32. See Electric Power and Renewable Energy in Florida, U.S. DEP'T OF ENERGY, http://apps1.eere.energy.gov/states/electricity.cfm/state=FL (last visited Oct. 10, 2010). Only California and Texas consume more. See Consumption, Price, and Expenditure Estimates, U.S. ENERGY INFO. ADMIN., http://www.eia.doe.gov/emeu/states/_seds.html (last visited Oct. 10, 2010).

33. See ACTION PLAN, supra note 4, at 3-1.

34. See ACTION PLAN, supra note 4 , at 17 (showing greatest potential for GHG reductions in energy supply sector compared with transportation/land use or agriculture, forestry and waste management); see also ELLIOTT ET AL., supra note 15, at 39.

35. See generally DSIRE, supra note 5 (searchable by state or policy/incentive category).

36. See id.

37. See id. In a recent example at the federal level, the American Recovery and Reinvestment Act of 2009, Congress awarded $\$ 16.8$ billion to the Department of Energy's Office of Energy Efficiency and Renewable Energy for its programs and initiatives. See American Recovery \& Reinvestment Act, U.S. DEP'T OF ENERGY, http://www1.eere.energy.gov/recovery (last visited Oct. 10, 2010). 
plant efficiency improvements, and demand-side management of power consumption. ${ }^{38}$ Reasons to pursue these policies extend beyond climate mitigation, however. According to the Action Plan, "[t] $]$ he fundamental policy objectives of encouraging renewable electricity generation are to reduce GHG emissions," but also to "provide fuel diversity, provide more energy security, and stimulate Florida's economy." ${ }^{39}$ The Legislature, likewise, declared that "it is in the public interest to promote the development of renewable energy resources in this state" because doing so can "diversify fuel types to meet Florida's growing dependency on natural gas for electric production, minimize the volatility of fuel costs, encourage investment within the state, improve environmental conditions, and make Florida a leader in new and innovative technologies." ${ }^{40}$ This goal is articulated in the State Comprehensive Plan as a policy to "[p]romote the use and development of renewable energy resources and low-carbon-emitting electric power plants." ${ }^{\text {11 }}$

\section{A. Existing Power Generation}

Despite the aspirational statements of support, renewable energy currently makes up less than 2 percent of the state's generation capacity ${ }^{42}$ Florida relies most heavily on natural gas for its power supply, followed by coal, nuclear, and oil. ${ }^{43}$ With the exception of nuclear energy, these resources emit GHG emissions at high levels. ${ }^{44}$ Absent policy mandates to alter the state's energy portfolio, Florida's reliance on natural gas is expected to surge to 57 percent by 2018, with coal still accounting for 15 percent and nuclear and oil-fired plants providing 13 percent. ${ }^{45}$

During the 1990s, many states restructured their electric industries to increase retail competition and consumer choice in power supplyessentially "the breaking out of generation services into a separate, more competitive segment of the industry while the transmission and

38. See ACrion Plan, supra note 4, at 3-5 tbl.3-1.

39. Id. at 3-8.

40. FLA. STAT. § 366.91(1) (2009); see also FLA. STAT. \& 366.81 (2009) ("Since solutions to our energy problems are complex, the Legislature intends that the use of solar energy, renewable energy sources, highly efficient systems, cogeneration, and load-control systems be encouraged.").

41. FLA. STAT. \& 187.201(11)(b)(9) (2009).

42. See Fla. Pub. Serv. Comm'n, Facts and Figures of the Florida Utility INDUSTRY 2 (2009).

43. See Fla. Pub. Serv. Comm'n, Facts and Figures of the Florida Utility INDUSTRY 21 (2009).

44. See, e.g., Independent Statistics and Analysis: Nuclear Power \& the Environment, U.S. ENERGY INFO. ADMIN., http://tonto.eia.doe.gov/energyexplained/index.cfm?page=nuclear_ environment (last visited Nov. 1, 2010) ("Unlike fossil-fuel fired power plants, nuclear power plants produce no air pollution or carbon dioxide. However, a small amount of emissions result from processing the uranium that is used in nuclear reactors.").

45. See FLA. RELIABILITY COORDINATING COUNCIL, supra note 42, at 31. 
distribution parts of the service remain largely regulated monopoly services. ${ }^{\prime 46}$ Florida was not among those states, and retains the traditional market structure in which utilities, regulated by the Public Service Commission (PSC), are granted franchise territories with the exclusive right to provide electric service. ${ }^{47}$ The state market is dominated by four regulated investor-owned utilities-Florida Power \& Light (FPL), Gulf Power, Progress Energy, and Tampa Electric - and the public JEA, which together supply over 80 percent of the electricity consumed in Florida. ${ }^{48}$ The rest of the state's power is supplied mostly by municipal electric utilities or rural electric cooperatives. ${ }^{49}$ In all, the state has generating capacity for approximately 56,000 megawatts (MW) of electricity, with transmission capacity to import approximately $3600 \mathrm{MW}$ more from out of state. ${ }^{50}$ This meets current demand while maintaining a 15-20 percent reserve margin. ${ }^{51}$

Recent years have seen energy consumption growing at a rapid rate in Florida. Thirty-three percent of Florida's generating capacity was developed in the last ten years alone, and it is expected that demand will continue to increase..$^{52}$ Although 2008 forecasts were revised and lowered to reflect impacts of the 2009 economic downturn, ${ }^{53}$ the Florida Reliability Coordinating Council still projects that increasing demand will require over $6500 \mathrm{MW}$ of new generating capacity by $2017 . .^{54}$

46. Brenda Buchan et al., Fla. Pub. Serv. Comm'n, Key Aspects of Electric RESTRUCTURING AND THEIR RELEVANCE FOR FloRIDA'S ELECTRICITY MARKET 6 (2000), available at http://www.psc.state.fl.us/publications/reports.aspx.

47. See Florida Electric Restructuring Not Active, U.S. ENERGY INFO. ADMIN, http:/www.eia.doe.gov/cneaf/electricity/page/restructuring/florida.html (last visited Feb. 1, 2010).

48. See Florida Electricity Profile, 2008, U.S. ENERGY INFO. ADMIN. tbl.3, http://www.eia. doe.gov/cneaf/electricity/st_profiles/florida.html (last visited Oct. 10, 2010).

49. See Fact Sheet, FlA. MUN. ELEC. ASS'N, http://www.publicpower.com/pdf $/$ fmea_factsheet.pdf (last visited Nov. 1, 2010).

50. See Fla. Pub. Serv. Comm'N, Facts and figures of the Florida Utility INDUSTRY 1 (2009).

51. See Fla. REliABILITY COORDINATING COUNCIL, supra note 42, at 5.

52. See Governor's action team on Energy and Climate Change, Phase 1 REPORT: Florida's ENERGy AND Climate CHANGE ACTION Plan 12 (2007). A map depicting the approximate locations of all of Florida's power plants is available on the Florida Department of Environmental Protection's website, http://www.dep.state.fl.us/Air/emission/ construction/power09.pdf (last visited Jan. 2010).

53. See Fla. Reliability CoORdINATING CoUNCIL, supra note 42, at 4, 17. See also TenYear Site Plans, FLA. PUB. SERV. COMM'N., http://www.psc.state.fl.us/utilities/electricgas/ 10yrsiteplans.aspx (last visited Oct. 10, 2010).

54. See Fla. Reliability COORDINATINg CoUNCIL, supra note 42, at 23. 


\section{B. Renewable Energy Potential}

Renewable energy potential varies state to state, and definitions of "renewable energy" vary as well. ${ }^{55}$ Section 366.91(2)(d) of Florida Statutes defines renewable energy broadly:

"Renewable energy" means electrical energy produced from a method that uses one or more of the following fuels or energy sources: hydrogen produced from sources other than fossil fuels, biomass, solar energy, geothermal energy, wind energy, ocean energy, and hydroelectric power. The term includes the alternative energy resource, waste heat, from sulfuric acid manufacturing operations. ${ }^{56}$

Florida's renewable resources are significant and largely untapped. A recent assessment of these resources determined that solar, biomass, and offshore wind have the highest technical potential for Florida, given a 2020 planning horizon. ${ }^{57}$ The study, performed by Navigant Consulting and commissioned by the Florida PSC, the Governor's Energy Office, and the Lawrence Berkeley National Laboratory, concluded that, depending on the interplay of key economic and regulatory factors, between 1800 and $16,000 \mathrm{MW}$ of renewable capacity could be installed in the state by 2020 , a range representing 6 to 27 percent of investor owned utilities' retail sales. ${ }^{58}$

\section{Solar Energy}

In Florida, solar energy has the highest near-term technical potential among renewable resources. ${ }^{59}$ Photovoltaic (PV) panels convert sunlight

55. As one scholar recently noted, "the federal government has not been a model of clarity," varying "the definition of renewable resources depending on the objective of each program." Steven Ferrey, Sustainable Energy, Environmental Policy, and States' Rights: Discerning the Energy Future through the Eye of the Dormant Commerce Clause, 12 N.Y.U. ENVTL. L.J. 507, 573-77, 645-71 (2004) (discussing variations in federal definitions of "renewable energy" and particular resources); see id. app. (listing state definitions).

56. FLA. STAT. \& 366.91(2)(d) (2009).

57. See Navigant Consulting, InC., Fla. Pub. Serv. Comm'n, Florida Renewable ENERGY POTENTIAL ASSESSMENT 188 (2008) [hereinafter NAVIGANT], available at http://www.psc.state.fl.us/utilities/electricgas/RenewableEnergy/FL_Final_Report_2008_12_29.p df (last visited Jan. 1, 2010). For additional useful (though in some places dated) information on renewable energy technologies and activities in Florida, see Fla. Pub. SERV. COMm'N, AN ASSESSMENT OF RENEWABLE ElECTRIC GENERATING TECHNOLOGIES FOR FloRIDA (2003), available at www.floridapsc/org/publiccations/pdf/electricgas/Renewable_Energy_Assessment .pdf.

58. See NAVIGANT, supra note 57 , at 23 . The study projected technical potentials for each resource, which it then constrained in accordance with favorability scenarios, accounting for the influence of factors such as fossil fuel prices, cost of carbon under greenhouse gas emissions policies, federal and state renewable energy tax credits and other incentives, the availability and cost of debt and equity, and the rate cap established for the purchase of renewable energy credits. See id.

59. See id. at 12. This and all subsequent Navigant estimates of technical potential cited here are based on the 2020 timeframe unless otherwise stated. 
directly into electricity. Panels can be installed on commercial or residential structures, producing energy onsite, or they can be utilized in a ground-mounted array for large-scale energy production. According to the Navigant study, there is significant potential from rooftop PV - an estimated 52,000 $\mathrm{MW}^{60}$ - as well as $37,000 \mathrm{MW}$ from ground-mounted PV arrays. ${ }^{61}$ Nonetheless, although rooftop PV is available and in use across the state, market penetration remains low. ${ }^{62}$ Florida's first large-scale solar array was completed in October 2009-a 25-MW PV facility in DeSoto County. ${ }^{63}$ Several other solar projects are in various stages of development, including a 110-MW PV installation at Kennedy Space Center $^{64}$ and a planned 400 -acre array to supply $75 \mathrm{MW}$ to the planned new town of Babcock Ranch. ${ }^{65}$

Potential for non-PV solar power is considered to be limited in Florida.${ }^{66}$ Large-scale solar thermal power plants that concentrate solar power to heat water and generate electricity using a steam turbine are not considered viable, and very modest potential exists for hybrid concentrated solar power systems, which combine solar energy with a non-renewable energy source. ${ }^{67}$ One such project is currently underway, a 75 MW solar thermal steam generating facility sited at FPL's existing nuclear plant in Martin County. Although it will be among the largest solar thermal facilities in the world, ${ }^{68}$ according to the Navigant study, potential for other such projects tops out at a low $305 \mathrm{MW}$ statewide. ${ }^{69}$

60. See id. at 40 (including residential and commercial, and assuming "combination of growing roof space and improved efficiency").

61. See id. at 41.

62. See Fla. Pub. Serv. Comm'n, Review of 2009 Ten-Year Site Plans 2-3 (2009) ("Currently, Florida's utilities report approximately 600 residential interconnections with a total capacity of approximately $2.8 \mathrm{MW}$.").

63. See DeSoto Next Generation Solar Energy Center, FLA. POWER \& LiGHT, http://www.fpl.com/environment/solar/desoto/shtml (last visited Jan. 1, 2010).

64. See Jim Waymer, Solar Energy Plant at KSC Generates Jobs, FLORIDATODAY.COM (Nov. 20, 2009), http://pqasb.pqarchiver.com/floridatoday/access/1905930421.html?FMT= ABS\&amp;date $=$ Nov $+20 \% 2 \mathrm{C}+2009$.

65. See Babcock Ranch: Solar Energy Facility, BABCOCK RANCH, http://www.babcockranchflorida.com/solar.asp (last visited Oct. 10, 2010).

66. See NAVIGANT, supra note 57 , at 58.

67. See id. at 57-58.

68. Fla. Pub. Serv. Comm'n, annual Report on ACtivities Pursuant to the FLORIDA ENERGY EFFICIENCY AND CONSERVATION ACT 21 (2009). This facility would not provide new generating capacity, but would "serve as a 'fuel substitution' resource." Id.

69. See NAVIGANT, supra note 57 , at 58. 


\section{Biomass}

Biomass, traditionally conceived, is plant matter, typically from agricultural waste or timber waste. ${ }^{70}$ Florida defines biomass much more broadly, however, to extend beyond forests and crops to include municipal solid waste, animal waste, and landfill gas. Under section 366.91(2)(a) of Florida Statutes,

"Biomass" means a power source that is comprised of, but not limited to, combustible residues or gases from forest products manufacturing, waste, byproducts, or products from agricultural and orchard crops, waste or coproducts from livestock and poultry operations, waste or byproducts from food processing, urban wood waste, municipal solid waste, municipal liquid waste treatment operations, and landfill gas. ${ }^{71}$

There are a number of methods for producing power using biomass, the most common of which is burning plant matter to heat water, creating steam that drives a turbine to generate electricity. Other methods include co-firing, which mixes biomass with fossil fuels, and gasification, which converts biomass to gas that can be burned or used in place of natural gas in a gas turbine. ${ }^{72}$ Methane, a greenhouse gas resulting from decay of organic materials in a landfill, can be captured and burned to produce electricity while reducing its release into the atmosphere. ${ }^{73}$

Forty-five states use biomass resources for electricity production, and twenty-five states (Florida not among them) increased biomass generation between 2006 and $2007 .^{74}$ Still, biomass, broadly defined, leads other renewable resources in terms of existing capacity in the state-most from municipal solid waste (MSW) (520 MW), followed by wood products $(380 \mathrm{MW})$, and agricultural byproducts $(191 \mathrm{MW}) .^{75}$ The Navigant study estimated biomass potential to be $5960-13,750 \mathrm{MW}$ of capacity. ${ }^{76}$

70. For a general overview of biomass as an energy resource, see Biomass Energy Basics, NAT'L RENEWABLE ENERGY LABORATORY, http://www.nrel.gov/learning/re_biomass.html (last visited Oct. 10, 2010).

71. FLA. STAT. $\$ 366.91(2)$ (a) (2009).

72. For a general overview of biopower generation methods, see Biopower, NAT'L RENEWABLE ENERGY LABORATORY, http://www.nrel.gov/learning/re_biopower.html (last visited Oct. 10, 2010).

73. See id.

74. See DORIS ET AL., supra note 5, at $42,186$.

75. See NAVIGANT, supra note 57 , at 10 . For a map depicting existing biomass facilities, see Bioenergy in Florida Factsheet, SE. AGRIC. \& FORESTRY ENERGY RESOURCES ALLIANCE, http://www.saferalliance.net/projects/downloads/data_pages/FL_roadmap_data.pdf (last visited Oct. 10, 2010).

76. See NAVIGANT, supra note 57 , at 14. 


\section{Wind Energy}

Nationwide, wind energy is the fastest growing renewable energy source. ${ }^{77}$ Large-scale energy production from wind can be achieved using a "farm" of two- or three-blade turbines with heights typically ranging "from 52.6 to 100 meters" aboveground or offshore. ${ }^{78}$ Wind energy also has small onsite applications where suitable conditions exist. ${ }^{79}$ There are already numerous wind facilities in the United States, generating over $35,000 \mathrm{MW}$ nationwide, ${ }^{80}$ but the potential for wind energy onshore in Florida is miniscule at an estimated $186 \mathrm{MW} .^{81}$ The few viable onshore sites for wind development are along the coast. ${ }^{82}$ FPL has proposed one coastal wind facility on Hutchinson Island in St. Lucie County, but the application has been stalled for some time in review. ${ }^{83}$

By contrast, the Navigant study identified over 40,000 MW in potential capacity for offshore wind energy in Florida. ${ }^{84}$ The accuracy of this wind potential projection is now being tested through a pilot study by the Florida State University Center for Ocean-Atmospheric Prediction Studies. ${ }^{85}$ In any event, offshore wind is far behind onshore wind from a market standpoint, and no offshore wind energy facilities are operational in U.S. waters to date. While this is likely to change soon in other states, none of the projects in development are off the coast of Florida. ${ }^{86}$

77. See U.S. DEP'T OF ENERGY, 20\% WIND ENERGY BY 2030: INCREASING WIND ENERGY'S CONTRIBUTION TO U.S. ELECTRICITY SUPPLY 5-6 (2008), available at http://wwwl.eere.energy.gov/windandhydro/pdfs/41869.pdf.

78. See AM. WIND ENERgy Ass'N, AWEA WIND POWER VAlue ChaIN 3, available at www.awea.org/pubs/factsheets/value_chain.pdf (last visited Oct. 16, 2010).

79. For an overview of power production using wind, see Wind Energy Basics, NAT'L RENEWABLE ENERGY LABORATORY, http://www.nrel.gov/learning/re_wind.html (last visited Oct. 10, 2010).

80. See AM. WIND ENERGy Ass'N, AWEA YEAR END 2009 MARKET REPORT 2 (2010), available at http://www.awea.org/publications/reports/4Q09.pdf.

81. See NAVIGANT, supra note 57 , at 13 . Even this low estimate is provided with a caveat that "a high resolution wind map is needed to confirm this assessment." Id. at 65.

82. See id.

83. See generally Proposed St. Lucie County Wind Project, FLA. POWER \& LIGHT, http://www.fpl.com/environment/wind/psl.shtml (last visited Jan. 1, 2010).

84. See NAVIGANT, supra note 57, at 13.

85. See SHAWn SMith ET AL., CTR. FOR OCEAN-ATMOSPHERIC Prediction Studies, THE POWER OF WIND: NEW INVESTIGATIONS INTO THE VIABILITY OF HARNESSING OFFSHORE WIND ENERGY FOR FLORIDA (2010), available at http://www.coaps.fsu.edu/docs/ offshorewindenergyfactsheet.pdf.

86. See U.S. OFFShORE Wind Collaborative, STATUS OF U.S. OFFShORE Wind DEVELOPMENT ACTIVTTY BY STATE (2008), available at http://www.usowc.org/odfs/ Stateoffshorewind.pdf (finding no activity in Florida, but finding activity in nearly every other east coast state); see also NAVIGANT, supra note 57, at 62. 


\section{Ocean Energy}

The ocean is a potential source of electricity based on wave energy, thermal energy, and ocean and tidal currents. The greatest potential for Florida appears to lie with submerged water turbines capturing ocean current energy from the Gulf Stream off the Atlantic coast. ${ }^{87}$ The Navigant study estimates a theoretical capacity between 4000 and 10,000 MW from ocean currents, but a technical potential of only $750 \mathrm{MW}$ by $2020{ }^{88}$ Ocean Renewable Power Company, LLC has preliminary permits from the Federal Energy Regulatory Commission (FERC) to develop at six sites in the Gulf Stream off Florida's coast. ${ }^{89}$ There are currently no operational commercial systems. ${ }^{90}$

Other methods for harnessing ocean energy are either unlikely to be operational in the near term or have low potential in Florida. Ocean thermal energy conversion is a method for generating energy based on the temperature differential between cold and warmer ocean waters. ${ }^{91}$ Although conversion systems can be located onshore or offshore, it is assumed that offshore is more viable in Florida. ${ }^{92}$ This, too, is a developing technology - no operational commercial systems currently

87. For an overview of ocean current energy, see Alternative Energy and Alternative Use Guide, Ocean Current Energy, OCS ALTERnative EnERgy AND Alternate Use PROGRAMMATIC EIS INFO. CTR., http://ocsenergy.anl.gov/guide/current/index.cfm (last visited Nov. 2009).

88. See NAVIGANT, supra note 57 , at 159 (resting even this "technical" projection on a range of uncertainties).

89. See NAVIGANT, supra note 57 , at 164; Florida, OCEAN RENEWABLE POWER COMPANY, http://www.oceanrenewablepower.com/ocgenproject_florida.htm (last visited Oct. 10, 2010).

90. See Alternative Energy and Alternative Use Guide, Ocean Current Energy, OCS alternative ENERgy and Alternate USE Programmatic EIS INFo. CTR., http://ocsenergy.anl.gov/guide/current/index.cfm (last visited Nov. 1, 2009). The Minerals Management Service (MMS) of the U.S. Department of Interior and the Federal Energy Regulatory Commission (FERC) recently released guidance on the regulation of hydrokinetic energy projects on the Outer Continental Shelf. Under a Memorandum of Understanding between the agencies, the MMS issues leases for such projects, while FERC has jurisdiction to issue construction and operational licenses. See Memorandum of Understanding between the U.S. Dep't of the Interior and the and Fed'l Energy Regulatory Comm'n (Apr. 9, 2009), available at http://www.boemre.gov/offshore/AlternativeEnergy/PDFs/DOI_FERC_MOU.pdf; U.S. DEP'T OF INTERIOR, GUidELINES FOR THE MiNERALS MANAGEMENT SERVICE RENEWABLE ENERGY FRAMEWORK 31-43 (2009).

91. For an overview of ocean thermal energy conversion, see What is Ocean Thermal Energy Conversion?, NAT'L RENEWABLE ENERGY LABORATORY, http:/www.nrel.gov/ otec/what.html (last visited Oct. 10, 2010); see also Ocean Thermal Energy Conversion, U.S. DEP'T OF ENERGY, http://www.energysavers.gov/renewable_energy/ocean/index.cfm/ mytopic $=50010$ (last visited Nov. 1, 2009).

92. See NAVIGANT, supra note 57, at 172 ("Developers have said that, due to Florida's hurricane hazards, any [ocean thermal conversion] development would likely take place on an offshore floating platform rather than onshore," but that systems will "not likely be available before the year 2020."). 
exist and none are expected to be available before $2020 .^{93}$ Wave energy is derived from the surface of waves or from pressure fluctuation beneath the surface. ${ }^{94}$ Significant potential for wave energy exists only in certain parts of the world, where waves are especially strong. Domestically, only the northwest is considered "wave-power rich." energy, which can be harnessed using a dam, tidal fence, or turbine, is not considered to have significant potential in Florida. ${ }^{96}$

\section{EXISTING LEGAL FRAMEWORK FOR SITING ENERGY FACILITIES}

A number of federal agencies have regulatory jurisdiction affecting aspects of energy production and markets. FERC, for example, regulates wholesale electricity rates and hydroelectric facilities, while the Department of Energy supports energy research and develops federal energy policy, among other things. ${ }^{97}$ The Department of the Interior regulates natural resource extraction on and offshore, while the Environmental Protection Agency administers pollution control and other statutes that implicate energy generation. ${ }^{98}$

93. See id. at 163-64.

94. For an overview of wave energy, see Alternative Energy and Alternative Use Guide, Ocean Wave Energy, OCS ALTERNATIVE ENERGY AND ALTERNATE USE PROGRAMMATIC EIS INFO. CTR., http://ocsenergy.anl.gov/guide/wave/index.cfm (last visited Nov. 1, 2009).

95. See id.

96. See NAVIGANT, supra note 57 , at 171. Because of their low potential for power generation, several other renewable energy sources were not assessed in detail in the Navigant study. Waste heat from "sulfuric acid manufacturing operations" is included in Florida's definition of "renewable energy" and refers to the heat produced from machine operations that can be redirected and reused onsite in a number of ways, including to generate electricity. See NAVIGANT, supra note 57 , at 153 . In Florida, sulfuric acid manufacturing is integral to the phosphate fertilizer industry. See id. at 152. According to the Navigant study, Florida has already installed twenty sulfuric acid manufacturing operations with capacity to produce $370 \mathrm{MW}$. See id. at 153 . This accounts for approximately 75 percent of potential generation, with only another 140 MW of remaining potential available. See id. at 145-56. Geothermal energy, which derives from heat trapped underground, is not considered viable for large-scale use in Florida. See id. at 182. For a general overview of geothermal energy, see Geothermal Technologies, NAT'L RENEWABLE ENERGY LABORATORY, http://www.nrel.gov/geothermal (last visited Dec. 1, 2009). Hydroelectric dams currently provide $55.7 \mathrm{MW}$ of capacity in Florida, but the technical potential for new facilities of this kind is minimal, especially in light of the significant environmental harms associated with dam construction. See NAVIGANT, supra note 56, at 181 . Renewablesourced hydrogen, from renewably generated electricity or biomass, has potential in the more distant future. See id. at 184. One method for producing power from hydrogen - the use of fuel cells-is not yet commercially viable, and the second method-mixing hydrogen in gas turbines - is still in research and development. See id. at 185-86.

97. See generally FED. ENERGY REGULATORY COMM'N, http://www.ferc.gov (last visited Oct. 10, 2010); U.S. DEP'T OF ENERGY, http://www.doe.gov (last visited Oct. 10, 2010).

98. See generally U.S. DEP'T OF THE INTERIOR, http://www.doi.gov (last visited Oct. 10, 2010); U.S. ENVTL. PROT. AGENCY, http://www.epa.gov (last visited Oct. 10, 2010). 
By contrast, siting energy infrastructure has traditionally been left to the states and local governments, ${ }^{99}$ though this is changing in some respects, in particular with transmission line siting. ${ }^{100}$ This Part provides an overview of the existing legal framework for land-based energy siting in Florida. Chapter 403, Part II of Florida Statutes governs most largescale power plant siting, while smaller facility siting is largely governed by Chapter 163, Part II of Florida Statutes, which mandates the basic structure for local land use planning and decision making.

\section{A. Energy Infrastructure Planning in Florida}

The regulatory backdrop for siting energy facilities is the PSC process for determining whether a need for new projects exists. Because Florida lacks statewide integrated resource planning, its planning framework is essentially utility driven. ${ }^{101}$ Each year, the largest Florida utilities submit ten-year power plant site plans that estimate "the utility's power generating needs and the general location of its proposed power plant sites over the ten-year planning horizon." 102 There are no formal constraints on utility choice in selecting the energy resource or general location for proposed power plants identified in the site plans. The PSC

99. See Tampa Elec. Co. v. Garcia, 767 So. 2d 428, 436 (2000) (dismissing preemption claims on the basis that power-plant siting and need determination are areas that Congress has expressly left to the states); see also NAT'L COMM'N ON ENERGY POL'Y, supra note 8, at 9 ("Primary authority to review and approve proposals for most other types of energy infrastructure-including power plants, electrical transmission lines, oil refiners, and other facilities - has, however generally resided with a variety of state agencies.").

100. The 2005 Energy Policy Act expanded FERC's authority to include transmission siting decisions under certain circumstances in specified transmission-capacity constrained areas. See 16 U.S.C. $\$ 824 \mathrm{p}(\mathrm{a})(2)(2009)$. For a discussion of shifting authority over transmission siting and implications, see, e.g., Jim Rossi, The Trojan Horse of Electric Power Transmission Line Siting Authority, 39 ENVTL. L. 1015 (2009) (arguing that recent debates over siting authority obscure more important considerations for energy policy).

101. Integrated resource planning has been defined as "Planning for electric power needs that accomplishes specified social and environmental goals by considering both demand-side management (to reduce electricity demand) and supply-side management (to redistribute types of generation among fuel types, locations, etc.). A public planning process to evaluate the optimal mix of utility resources and options." Body of Knowledge on Infrastructure Regulation: Glossary, Integrated Resource Planning, UNIV. OF FlA. PUB. UTIL. RESEARCH CTR., http://www.regulationbodyofknowledge.org/glossary/define/Integrated\%20resource \%20plannin g\%20\%28IRP\%29 (last visited Oct. 10, 2010); see, e.g, NAVIGANT, supra note 57, at 4 (noting that the study can only be considered preliminary given that a "statewide Integrated Resource Planning process would need to be undertaken to understand how [renewable energy] would fit in with: Florida's current and planned generation assets; current transmission infrastructure and potential future requirements"). Individual utilities, however, do engage in integrated resource planning. See, e.g., Fla. Power \& Light, Ten Year Power Plant Site Plan: 2010-2019, at 52 (2009), available at http://www.fpl.com/about/ten_year/pdf/plan.pdf.

102. Fla. Pub. Serv. Comm'N, Review of 2009 Ten-Year Site Plans 1 (Oct. 2009). Chapter 186, Florida Statutes, requires that each generation electric utility in the State of Florida must annually submit a ten-year power plant site plan. See FLA. STAT. §186.801(1) (2009). 
performs a preliminary review of the site plans and classifies them simply as "suitable" or "unsuitable" for planning purposes. ${ }^{103}$

Proceeding from a "suitable" site plan, a utility proposes a new power plant through a petition for determination of need. Under $\S$ 403.519 , Florida Statutes, the "need" to be determined is utility needthat is, demand of the utility's particular customer base for more power. ${ }^{104}$ With no RPS or similar instrument in place, there is no utility "need" for renewable versus nonrenewable energy. Nevertheless, although the state's (and the nation's) generalized need to derive energy from renewable resources does not frame the inquiry, the Legislature recently expanded the range of factors relevant to a need determination. In addition to "the need for electric system reliability and integrity ..., the need for adequate electricity at a reasonable cost," and "whether the proposed plant is the most cost-effective alternative available," the PSC must now also consider "the need for fuel diversity and supply reliability" and "whether renewable energy sources and technologies, as well as conservation measures, are utilized to the extent reasonably available."105 "Reasonably available" is by no means a stringent standard, but the PSC interprets these directives as granting "broad authority to determine how each of these criteria may be weighted to address the continuous evolution of the electric industry" and "the discretion to determine the need for an electrical power plant based upon one or more of the qualifications [in $\S 403.519(3)$ ] so long as each has been considered as a component of the final decision." 106

103. See FLA. STAT. $\$ 186.801(2)$ (2009). The statute requires the commission to evaluate a range of issues when reviewing ten-year site plans for suitability. See id. $\$ 186.801(2)(\mathrm{a})-(\mathrm{g})$.

104. See Tampa Elec. Co. v. Garcia, 767 So. $2 d$ 428, 434 (Fla. 2000); Nassau Power Corp. v. Beard, 601 So. 2d 1175, 1178 (Fla. 1992) (rejecting argument that need determination should be based on projected statewide electric utility need).

105. FLA. STAT. \& 403.519(3) (2009) (the "fuel diversity" language was added in 2006 Fla. Laws, ch. 230, s. 43, and the "renewable energy sources" language was added in 2007 Fla. Laws, ch. 117, s. 3). Albeit a bit repetitively given the 2007 additions, the section also requires the commission to "consider the conservation measures taken by or reasonably available to the applicant or its members which might mitigate the need for the proposed plant." Id. Cost considerations are narrowly associated with the facility proposed, versus a broader cost analysis accounting for climate impacts. See FLA. ADMIN. CODE ANN. r. 25-22.082 (2009) (employing requests for proposals as prerequisite to petition for need determination as a "means to ensure that a public utility's selection of a proposed generation addition is the most cost-effective alternative available"); see also FLA. ADMIN. CODE ANN. r. 25-22.081 (2009) (requiring cost information related solely to construction and operation of the proposed plant); FLA. ADMIN. CODE ANN. r. 25-22.081(1)(b) (2009) (asking for "general description of the proposed electrical power plant, including the size, number of units, fuel type and supply modes, the approximate costs") (emphasis added).

106. Memorandum, Docket No. 090451-EM, Fla. Pub. Serv. Comm'n, Div. of Regulatory Analysis to Office of Comm'n Clerk 3 (Jan. 28, 2010) (recommending petition for determination of need be granted to Gainesville Regional Utilities for $100 \mathrm{MW}$ biomass power plant); see also Glades Power Park, 260 P.U.R. 4th 158, 2007 Fla. PUC LEXIS 342, at *6 (Fla. P.S.C. 2009) (denying petition for new coal plant, noting, "The Legislature did not assign the weight that this 
A need determination does not entitle a utility to build at a particular site or any site at all, but it creates a presumption of public need for the proposed plant that cannot be revisited and that carries over into the siting approval process discussed below. ${ }^{107}$ In practice, then, the need determination functions as generic state approval to build a large power plant. At the siting stage, the question is not whether a facility will be built, but where. ${ }^{108}$

\section{B. The Electrical Power Plant Siting Act}

Florida's Electrical Power Plant Siting Act (Siting Act) ${ }^{109}$ provides a centralized licensing process for large power plants. The Siting Act applies to steam or solar electrical generating facilities that generate 75 MW or more and were constructed after October 1, $1973 .{ }^{110}$ State records of Siting Act applications show this capacity threshold is well suited for proposals to construct coal-fired plants, natural gas plants, and nuclear power plants-traditional, non-renewable power projects, which account for the vast majority of Siting Act applications to date. ${ }^{111}$ Over seventy applications for certification or modification have been processed under the Siting Act, the majority of which have been approved, or "certified." $" 112$ Only two certifications were denied. ${ }^{113}$

Before seeking authorization to site a power plant, a utility must already have obtained its need determination from the PSC ${ }^{114}$ With this in hand, the Siting Act offers distinct benefits for qualifying utility-scale

Commission is to give each of these factors."). For examples of how the commission has implemented the new language in recent need determination proceedings, see, e.g., Greenland Energy Center, Docket No. 080614-EM, 2009 Fla. PUC LEXIS 67 (Fla. P.S.C. 2009) (granting petition for a natural gas power plant); West County Energy Center, $2008 \mathrm{Fla}$. PUC LEXIS 413 (Fla. P.S.C. 2008) (granting petition for natural gas power plant and conversions of existing units for improved efficiency).

107. See $\S 403.519(3)$. The determination also serves as the Commission's report required as part of the Siting Act review procedures. $I d$.

108. The Commission is the exclusive forum for need determination. See $\S 403.519(3)$. In this sense, energy policy and siting policy are kept largely separate; assumptions underlying a need determination cannot be reexamined during Siting Act certification. Id. This bifurcation of need and siting, right or wrong, has implications for public participation at the local level: by the time members of a community learn that a power plant is being sited there, the question of whether it is needed is no longer open for debate. Members of the public can participate in the need determination proceedings, but by divorcing need from siting, those who will be affected are typically not engaged at that early stage.

109. FLA. STAT. $\$ \S 403.501-.518(2009)$.

110. See $\S \S 403.503(14), .506(1)$.

111. See Certified Facilities-Power Plants Transmission Lines, FLA. DEP'T OF ENVTL. ProT. (Apr. 20, 2009), http://www.dep.state.fl.us/siting/power_plants.htm.

112. See id.

113. Nine applications have also been withdrawn from the Siting Act process since its inception. See id.

114. See $\S 403.507(4)$. 
projects. First and most essentially, the Siting Act employs a single license, termed a "certification," that supplants all local and state permits or approvals that would otherwise be required for a major industrial use. ${ }^{115}$ The Florida Department of Environmental Protection (DEP), through a Siting Coordination Office, serves as a single point of contact for utility applicants during the permitting process. ${ }^{116}$ This consolidation allows a single application encompassing what would otherwise be individual applications for each necessary state and local permit or approval, as well as state-administered federal permits. ${ }^{17}$ The single license feature of the Siting Act affords potentially significant time and financial savings by eliminating duplication of effort and uncertainty about what permits are required. To further expedite the process, applicants can submit a notice of intent to file an application, which entitles them to enter into "binding written agreements" with the DEP and other state agencies as to the "scope, quantity, and level of information to be provided in the application, as well as the methods to be used in providing such information, and the nature of the supporting documents to be included." 118 This reduces time wasted on producing unnecessary information and limits the agency's ability to prolong the process with requests for additional information not identified in the agreement.

Second, the Siting Act supplants the Growth Management Act's procedural framework and shifts ultimate siting authority from the local government to the state. Typically, local governments control industrial facility siting within their jurisdictional boundaries. For power plants, the Siting Act provides a substitute procedure called the "land use consistency determination." 119 Affected local governments participate by filing a short pleading stating whether or not a proposed power plant site is consistent with the local comprehensive plan and zoning ordinances. If the local government determined the project to be inconsistent, it must "include a statement of what would need to be done to make the proposed project consistent." 120 If the local government issues an affirmative determination, a substantially affected party can challenge it, and a preliminary hearing will be held on the isolated issue of land use consistency. ${ }^{121}$ However, in the event of persistent local government

115. See § 403.511.

116. See $\$ 403.504$.

117. See $\$ \$ 403.503(16), .511(3)$.

118. $\$ 403.5063$.

119. See $\$ \S 403.50665,403.508$.

120. Fla. AdMIN. CODE ANN. r. 62-17.121(2) (2009).

121. See FLA. STAT. $\S \S 403.50665(4), .508(1)$. The land use consistency determination process is similar in many ways to the Growth Management Act (GMA) process procedurally, and it is common for utilities to obtain land use changes prior to submitting a site certification application to DEP under the GMA structure. For example, Gilchrist County proposed a 
objection, the Governor and Cabinet, sitting as the Power Plant Siting Board, nonetheless retain the power to approve the site if "it is in the public interest to authorize the use of the land for a site or associated facility"-a clear incentive for the local government to work with the utility in approving a site. ${ }^{122}$

Third, the Siting Act moves an application through the process quickly, considering the size and scope of utility-scale power plants. It establishes statutory deadlines that structure the review and requires the DEP to propose a schedule of pertinent dates for the application within seven days of its formal filing. ${ }^{123}$ These deadlines offer a reasonably predictable timetable for process and review-applicants can expect to have a request for certification approved or denied within thirteen to eighteen months. ${ }^{124}$

Fourth, the review and approval process for certification is itself a legal proceeding that is docketed at the outset with the Division of Administrative Hearings. ${ }^{125}$ This feature creates a clear, enforceable, and time-limited structure for the review process. ${ }^{126}$ It also offers potentially significant time and financial savings by requiring agency review to be conducted in the forum where potential administrative challenges would otherwise be heard subsequent to final agency action. ${ }^{127}$ Under the Siting Act, such challenges are incorporated into the review process itself, thereby reducing the bases for post-certification litigation.

Finally, the Siting Act allows the Governor and Cabinet unilateral authority to approve conditions in a certification that depart from "nonprocedural," that is, substantive, "requirements of agencies" that would otherwise be applicable to the power plant. ${ }^{128}$ For purposes of the

comprehensive plan amendment to change 520 acres in the agricultural land use category to the public land use category, amending the text of the plan to allow electrical generating facilities as a public land use. See Fl.A. DEP'T OF CMTY. AFF., OBJECTIONS, RECOMMENDATIONS, AND COMMENTS REPORT FOR THE GILCHREST COUNTY COMPREHENSIVE PLAN AMENDMENT 09-1 (2009), available at http://www.dca.state.fl.us/fdcp/dcp/Procedures/ReturnNoiOrcReports.cfm? ORCSelectMunicipality=GILCHRIST+CO\&OrcDocType=Yes\&NoiDocType=Yes\&Submit $=S$ ubmit+Your+Request (raising a range of objections).

122. See $\$ 403.508(\mathrm{f})$.

123. See $\S 403.5064(4)$.

124. See E-mail from Mike Halpin, Director, Siting Coordination Office, DEP, to author (Sept. 2009) (on file with author).

125. See $\S 403.5065$ (providing that within seven days of an application's filing date, the DEP must request assignment of an administrative law judge and docket the application).

126. See $\S 403.5064(2)$. A schedule of deadlines is contained within an order of the administrative law judge based on the proposed schedule developed by the DEP.

127. See $\$ \S 403.526, .527$ (addressing agency reports and hearing participants, respectively).

128. See $\S 403.511$ (1)(b) (providing that, as a general rule subject to specified exceptions, "certification may include conditions which constitute variances, exemptions, or exceptions from nonprocedural requirements of the department or any agency which were expressly considered during the proceeding, including, but not limited to, any site specific criteria, standards, or limitations under local land use and zoning approvals which affect the proposed electrical power 
Siting Act, "nonprocedural requirements of agencies" is defined very broadly to include "any agency's regulatory requirements established by statute, rule, ordinance, zoning ordinance, land development code, or comprehensive plan, excluding any provisions prescribing forms, fees, procedures, or time limits for the review or processing of information submitted to demonstrate compliance with such regulatory requirements." ${ }^{129}$

If all land use issues are resolved and certification is not otherwise challenged, the Secretary of the DEP has authority to issue the license. ${ }^{130}$ For contested projects, final certification issues from the Siting Board, which approves or denies an application based on whether "the location, construction and operation of the electrical power plant" will serve a

plant or its site, unless waived by the agency and which otherwise would be applicable to the construction and operation of the proposed electrical power plant").

129. $\$ 403.503(21)$. There are also benefits that accrue from other provisions of state law when a facility qualifies as a "power plant" under the Siting Act. For example, exemptions for certain "associated facilities" from all land use plans or zoning ordinances may be relevant in the land use determination, based on the statutory definition of "development." See FLA. STAT. \& 380.04(3) (2009). A non-exhaustive list of exempt associated facilities provided by DEP includes electrical transmission lines, natural gas pipelines, wastewater pipelines, and access roads, among others. See Land Use Consistency Determination, Fla. DEP'T OF ENVTL. Prot., http://www.dep.state.fl.us/siting/land_use_consistency.htm. (last visited Sept. 29, 2010). Likewise, the statute governing developments of regional impact exempts "[a]ny proposed electrical transmission line or electrical power plant." FLA. STAT. § 380.06(24)(b) (2009). The primacy of the Siting Act over all aspects of power plant siting is explicitly reinforced in other statutes as well. See e.g., FLA. STAT. $§ 377.703$ (2009) ("It is the specific intent of the Legislature that nothing in this act [pertaining to the Florida Energy and Climate Commission's duties] shall in any way change the powers, duties, and responsibilities assigned by the Florida Electrical Power Plant Siting Act, part II of chapter 403, or the powers, duties, and responsibilities of the Florida Public Service Commission.”).

130. See $\S 403.508(6)(2009)$. 
series of specified statutory goals. ${ }^{131}$ Once issued, a power plant certification remains in effect for the life of the facility. ${ }^{132}$

\section{The Growth Management Act}

Local land use planning and decision making in Florida is governed by the Growth Management Act (GMA), and energy facilities smaller than $75 \mathrm{MW}$ may require changing a land use designation pursuant to this Act. ${ }^{133}$ Significantly, however, no determination of need from the PSC is required. ${ }^{134}$

Under the GMA, local governments adopt comprehensive plans to guide development. Each plan is comprised of mandatory elements addressing a broad range of planning issues, from transportation to schools to conservation, including a future land use map depicting areas appropriate for particular land uses. ${ }^{135}$ Plans are implemented through land development regulations (LDRs), which more specifically describe how development should occur to further the goals and policies of the comprehensive plan. ${ }^{136}$

To site an energy facility smaller than $75 \mathrm{MW}$ (and thus not subject to the Siting Act), a land use change will be needed if the comprehensive

131. The criteria are set out in FLA. STAT. $\$ 403.509$ (3) (2009):

(a) Provide reasonable assurance that operational safeguards are technically sufficient for the public welfare and protection.

(b) Comply with applicable nonprocedural requirements of agencies.

(c) Be consistent with applicable local government comprehensive plans and land development regulations.

(d) Meet the electrical energy needs of the state in an orderly, reliable, and timely fashion.

(e) Effect a reasonable balance between the need for the facility as established pursuant to s. 403.519 and the impacts upon air and water quality, fish and wildlife, water resources, and other natural resources of the state resulting from the construction and operation of the facility.

(f) Minimize, through the use of reasonable and available methods, the adverse effects on human health, the environment, and the ecology of the land and its wildlife and the ecology of state waters and their aquatic life.

(g) Serve and protect the broad interests of the public.

The final order of the Siting Board is subject to appeal pursuant to FLA. STAT. $\S 403.513$ (2009), which allows review by a district court of appeal. See FLA. STAT. $\$ 120.68(2)$ (2009).

132. See $\$ 403.511(1)-(3)$ (2009). Amendments or modifications to a certification order, however, will trigger further agency review. See $\S \S 403.5113, .516$.

133. See FLA. STAT. \$§ 163.3164-.3217 (2009).

134. See $\$ 403.506$ (2009) (providing exemption from need determination requirement for power plants with capacity less than $75 \mathrm{MW}$ ).

135. No energy element is required. See $\S 163.3177(3)(a),(6)(2009)$. Nor is it identified as one of the optional elements encouraged by the GMA. See $\S 163.3177(7)$. A local government could adopt an energy element voluntarily, however. See $\S 163.3177(7)(k)$ (authorizing "other elements particular to, and necessary for, the area concerned").

136. See § 163.3201 (describing relationship between LDRs and comprehensive plans); $\S$ 163.3202 (setting out minimum requirements for LDRs). LDRs take the form of zoning ordinances or other regulations controlling development. See $\$ 163.3164(23)$. 
plan does not already contemplate that use for the parcel. ${ }^{137}$ The process in this sense is no different from any other land use change; a residential subdivision on land designated agricultural, for example, would also require a land use change. Because all development must conform to the comprehensive plan, a land use change requires a plan amendment. ${ }^{138}$ Plan amendments can be applicant-driven or adopted at the initiative of the local government as part of long-range planning or policymaking. As a general rule, comprehensive plans can be amended only twice a year. ${ }^{139}$ If a proposed energy facility is consistent with the comprehensive plan, it may still require rezoning or a special exception or variance from the more specific LDRs applicable to the site. ${ }^{140}$ For example, LDRs might specify height limitations or a narrow range of uses that preclude the proposed facility. Ultimately, a development order must be issued to authorize construction. ${ }^{141}$

The GMA sets out the procedural framework for changing a comprehensive plan to accommodate a new land use. ${ }^{142}$ An application for a land use change is submitted to the local government and assessed by the local planning agency, which makes a recommendation to approve or disapprove. ${ }^{143}$ At a "transmittal hearing," elected officials vote on whether or not to transmit the proposed amendment to the Department of Community Affairs (DCA). ${ }^{144}$ The DCA solicits comments from relevant agencies ${ }^{145}$ and reviews the plan amendment for consistency with the local plan, state law, and administrative rules. ${ }^{146}$ The DCA then sends a report back to the local government, which must address any objections, ${ }^{147}$ but can adopt the amendment at a hearing, with or without

137. New electrical substations are treated as permitted uses in all land use categories in the applicable comprehensive plan or zoning district, except preservation, conservation, or historic preservation on the future land use map. See $\S 163.3208(4)$. The locality can apply siting standards, however. See id.

138. See $\S 163.3194(1)(\mathrm{a})$.

139. See $\$ 163.3187$ (listing exceptions for amendments involving developments of regional impact, land use changes for ten or fewer acres, state correctional facilities, and brownfield developments, among other things).

140. See $\S 163.3213$ (describing administrative review of LDRs for consistency with comprehensive plan).

141. See $\$ 163.3164$.

142. The overview provided here assumes a land use change involving more than ten acres. If the parcel is ten acres or fewer, it is treated as a small-scale amendment and receives a streamlined version of this process. See $\S 163.3187(1)(c)$ (exempting small-scale amendments from twice-a-year adoption limitation).

143. See $\$ 163.3174$.

144. See $\S 163.3184(3)$.

145. See $\$ 163.3184(4)$.

146. Technically, the DCA has the option to forego this review unless it is formally requested, see $\$ 163.3177(6)$, but this has not been the practice of the agency.

147. See $\$ 163.3184(6)$ (c); FLA. ADMIN. CODE. ANN. r. 9J-11.009-.010 (2009). 
changes. ${ }^{148}$ The DCA performs a final review and publishes a finding that the amendment is either "in" or "not in" compliance. ${ }^{149}$ If the amendment is found not in compliance, or if an affected person with standing challenges a compliance finding, the DCA holds an administrative hearing. ${ }^{150}$ The DCA's final order can be appealed. ${ }^{151}$ Similar procedures are provided for changes to LDRs (rezonings), but with notably less involvement by the state. ${ }^{152}$

This overview highlights several key differences between the GMA and the Siting Act land use consistency determination. Under the Siting Act, consistency with the local comprehensive plan is a central but not controlling consideration. Under the GMA, consistency with the plan and the GMA itself control whether a plan amendment is valid. The Siting Act provides for preemption of local authority if the Siting Board deems the proposed power plant and selected site to be in the public interest. Under the GMA, by contrast, the state has no authority to preempt a local government decision-it is either in conflict with the law, or it controls. Indeed, the GMA does not even give "the state, either through the DCA or through the governor and cabinet, the authority to adopt, repeal, amend, or render ineffective, an adopted plan or plan amendment." ${ }^{53}$ Rather, "the 'teeth' of the Act is in the authority of the governor and cabinet to levy 'sanctions' . . . against a local government" that adopts an amendment that is out of compliance. ${ }^{154}$ The Siting Act moves a proposal through review according to a predictable schedule and minimizes litigation while projects under the GMA can stall at numerous points in the local process, and subsequent litigation is common.

In 2010, the Legislature changed this framework by giving local governments the option to expedite land use approval for renewable energy facilities otherwise governed by the GMA. ${ }^{155}$ The original

148. See FLA. STAT. $\S 163.3184(7)$ (2009).

149. See $\S 163.3184(8)$.

150. An "affected person" may challenge an adopted plan amendment found in compliance, or may intervene when DCA initiates a challenge. See \$163.3184(1)(a).

151. The forum and procedures for appeal depend on whether the amendment was determined in or not in compliance. For a useful overview of the public's role in Florida growth management and opportunities for participation, see [2] 1000 FRIENDS OF FLORIDA, COMMUNITY STEWARDSHIP: A CITIZEN'S GUIDE TO THE NUTS AND BOLTS OF FLORIDA'S Growth MANAGEMENT PROCESS (2004), available at http://www.1000friendsofflorida.org/ PUBS/Community\%20Steward\%20Handbooks/

CommStewII.pdf.

152. See id. at 32-37.

153. Richard Grosso, Florida's Growth Management Act: How Far We Have Come and How Far We Have Yet to Go, 20 NOVA L. REV. 589, 601 (1996).

154. See id.

155. See 2010 Fla. Laws ch. 205, s. 62 (S.B. 550) (amending FLA. STAT. $\$ 403.973$ (2009)). The new language provides, "Projects resulting in the production of biofuels cultivated on lands that are 1,000 acres or more or in the construction of a biofuel or biodiesel processing facility or a facility generating renewable energy, as defined in s. 366.91(2)(d), are eligible for the 
"expedited permitting" statute, enacted in 1996 to fast-track developments meeting job-creation criteria, made ineligible any project for which the primary purpose was to produce electrical power. ${ }^{156}$ The law has rarely been used and it remains to be seen, of course, how frequently local governments will opt to expedite siting for power plants, a choice that may fan the fire of any local opposition. Even when local governments opt not to expedite, however, renewable energy projects will benefit from procedural features of the new law, such as time-limited state agency review coordinated through "regional permit action teams," as well as consolidation of any legal challenges to the project in a single summary administrative proceeding. ${ }^{157}$

\section{Siting CONTEXT FOR RENEWABLE ENERGY RESOURCES}

Florida law makes few distinctions between the individual resources defined as "renewable energy," yet those resources vary substantially. They have marked differences in technical and geographic potential, in technological and market development, in environmental impacts, and in the siting context.

Many of the pertinent considerations for siting a traditional power plant can also arise with renewable energy. Does the site allow for interconnection to the electrical grid and transmission of the energy generated? How suitable is the land where the facility will be physically located? What impacts should be expected on surrounding land, water, and wildlife? How will the facility affect the local community? A wide range of legitimate concerns give rise to local opposition to new energy infrastructure of whatever kind, from the local environmental and health effects of a facility, to environmental justice in site selection, to perceived impacts on surrounding property values and aesthetic considerations. ${ }^{158}$ The answers to these questions are inevitably both resource- and sitespecific.

expedited permitting process." FLA. STAT. $\$ 403.973(3)(f)$ (2009), amended by 2010 Fla. Laws ch. 205, s. 62 (S.B. 550 ).

156. See FLA. STAT. $\$ 403.973(19)$ (2009). For a discussion of this statute, its origin, and its benefits from a developers' perspective, see Carolyn Raepple, Florida's Expedited Permit Review Process: Streamlining the Development of Florida's Economy, 25 FLA. ST. U. L. REV. 301 (1998).

157. See 2008 Fla. Laws ch. 205, s. 62 (amending FLA. STAT. \$ 403.973(3)(a), (7) (2009)).

158. See NAT'L COMM'N ON ENERGY POL'Y, supra note 8, at 9 (listing most common local concerns to proposed energy facilities). A significant body of literature examines the siting of locally undesirable land uses. See, e.g., KenNETH A. MANASTER, ENVIRONMENTAL PROTECTION AND JUSTICE: READINGS ON THE PRACTICE AND PURPOSES OF ENVIRONMENTAL LAW 201-326 (3d ed. 2007) (addressing siting of polluting facilities in depth); Richard Lazarus, Pursuing "Environmental Justice": The Distributional Effects of Environmental Protection, 87 Nw. U. L. Rev. 787 (1993); Vicki Been, What's Fairness Got To Do With It? Environmental Justice and the Siting of Locally Undesirable Land Uses, 78 CORNELL L. REv. 1001 (1993). 
Other considerations are peculiar to renewable resources. Most importantly, renewable energy facilities must be located where the resource is abundantly available. As a result, siting renewable energy often involves geographic constraints that do not apply to traditional power plants. ${ }^{159}$ Ideal locations for harnessing a resource may lack easy access to transmission infrastructure; this is a problem in particular for wind farms in remote rural areas of Texas and the Midwest. Similarly, locating a biomass plant for ready access to a feedstock may involve transporting the energy produced over a long distance to population centers.

From a regulatory standpoint, it is helpful to recognize that barriers to siting renewable energy can take several forms. Most obvious are barriers that affirmatively prevent or hamper siting, like restrictions on the use of rooftop solar panels. Barriers can also consist of regulatory gaps (the absence of standards needed to support grid interconnection, for example) or regulatory weaknesses (standards that are poorly conceived or otherwise ineffective). Finally, and probably less obvious, are barriers in the form of siting-related incentives or benefits that are available only or predominantly for non-renewable generation. For example, as this Part discusses at some length, the parameters for certification under the Siting Act inevitably exclude many renewable projects. The availability of statutory benefits for utility-scale projects may operate in the inverse as a measurable, if not insurmountable, barrier to smaller non-utility projects relative to their larger counterparts. Similarly, Florida law provides cost recovery for siting and related preconstruction costs for nuclear power plants, irrespective of whether the facility is in fact built. ${ }^{160}$ This multi-million dollar benefit provides a significant incentive to build nuclear power plants. ${ }^{161}$ Without the same provision for large-scale renewable projects, it may function as an inverse regulatory barrier relative to nuclear power. ${ }^{162}$ Noting the potential for

159. See VAJHALA, supra note 26 , at $5-6$.

160. See FlA. STAT. $\$ 366.93$ (2009). Costs must have been prudently incurred. See FlA. AdMIN. CODE ANN. r. 25-6.0423(1) (2009).

161. A thorough comparative analysis of incentives for renewable and non-renewable energy resources is outside the scope of this paper, as many do not deal so directly with siting, but some analyses are available. See, e.g., U.S. ENERGY INFO. ADMIN., supra note 22; UNITED NATIONS ENV'T PROGRAMME, REFORMING ENERGY SUBSIDIES: OPPORTUNITIES TO CONTRIBUte to THE ClimAte CHANGE AgENDA (2008), available at http://www.unep. org/pdf/PressReleases/Reforming_Energy_Subsidies.pdf (showing that majority of subsidies worldwide are directed to fossil fuels); ENVTL. LAW INST., ESTIMATING U.S. GOVERNMENT SUBSIDIES TO ENERGY SOURCES: 2002-2008 (2009), available at http://www.elistore.org/Data/products/d19_07.pdf (showing that majority of subsidies in the United States are directed to fossil fuels).

162. FPL obtained a similar cost-recovery for siting and pre-construction costs for three solar plants, though the statute was time-limited and is no longer available. See FLA. STAT. § 366.92 (2009). One amendment allows full cost recovery under the environmental cost recovery 
this disparity, the Governor's Climate Action Team recommended that "[r]enewable energy sources should receive subsidies at least equal to nuclear energy sources to level the playing field." 163

This Part takes up the regulatory context and key considerations for siting Florida's most immediately promising renewable energy resources: solar energy and biomass. Solar PV alone has the technical potential for $89,000 \mathrm{MW}$ of capacity by $2020 .{ }^{164}$ If it were possible to fully harness this resource, it would exceed the total existing generating capacity in the state. PV technology, both onsite and utility-scale, is already available and in use in the state. Biomass has lower, but still significant, potential, between 6000 and 13,750 MW of capacity. Biomass facilities are already operating in Florida and others are in various stages of development; like solar PV, the technology is available and in use, onsite and at utility scale. There is no meaningful wind potential onshore, ${ }^{165}$ but offshore wind and ocean energy have high potential in the longer term. ${ }^{166}$ At present, there are no active offshore wind or ocean energy projects in development off of Florida's coasts, and there is currently no regulatory framework designed to guide offshore siting in Florida waters. Other forms of renewable energy do not compare, either in technical potential or in stage of development. For all these reasons, solar energy and biomass are likely to be the dominant renewable energy resources in Florida for the foreseeable future.

\section{A. Siting Solar Energy}

Legislative interest in solar energy has a long history in Florida. Since the mid-seventies, it has been the intent of the Legislature "to encourage the development of an alternative energy capability in the form of incident solar energy." 167 More broadly, it is "the policy of this state to promote, stimulate, develop, and advance the growth of the solar energy industry in this state." ${ }^{\prime 168}$ The Florida Solar Energy Center was

clause for renewable energy projects that are zero greenhouse gas emitting at the point of generation up to a total of $110 \mathrm{MW}$. See $\S 366.92$ (c)(4). In 2008, the PSC approved FPL for cost recovery of three solar projects, totaling exactly $110 \mathrm{MW}$, thereby rendering the provision obsolete going forward. But see S.B. 1186, 112th Leg. (Fla. 2010) (proposing full cost recovery for certain renewable energy projects now available for other types of power plants).

163. ACTION PLAN, supra note 4, at A-15 (noting "the current $\$ 9 /$ month per household fee for nuclear").

164. See NAVIGANT, supra note 57, at 180 (combining projections for ground-mounted and rooftop PV).

165. At less than $200 \mathrm{MW}$, the potential amounts to about less than 1 percent of current generating capacity in Florida. See FLA. Pub. SERV. COMM'N, FACTS AND FigurES OF THE FLORIDA UTILITY INDUSTRY 1 (2009) (reporting Florida electricity generating capacity to be over $55,000 \mathrm{MW}$ ).

166. See NAVIGANT, supra note 57, at 180.

167. FLA. STAT. \$ 377.705 (2009).

168. Fla. STAT. $\$ 288.041(2)$ (2009). 
established in 1975 to be a research. center and testing and certification lab for solar PV systems. ${ }^{169}$

With increased interest in renewable energy over the last few years has come renewed attention to the possibilities for solar energy in Florida. In 2008, the Legislature directed the newly formed Florida Energy and Climate Commission to identify barriers to solar energy, develop goals and strategies to promote solar technology, and capitalize on opportunities in federal legislation to advance solar energy. ${ }^{170}$ Armed with a broad mandate, the Commission has the authority and opportunity to lay the groundwork for significant policy reforms in support of solar energy. ${ }^{171}$ This subpart focuses on siting solar PV, given its high potential in Florida compared with other forms of solar power generation. ${ }^{172}$ Plainly, the siting context and concerns for large-scale solar arrays compared with rooftop installations are quite different. This subpart discusses each in turn.

\section{Ground-Mounted Photovoltaic Arrays}

\section{a. Regulatory Context}

The legal framework for siting large-scale PV facilities depends on the size. For solar power plants with $75 \mathrm{MW}$ of generation capacity or more, the Power Plant Siting Act structures the siting review process. As Part II detailed, the Siting Act provides utility-scale energy facilities with a number of benefits: a single point of contact for all state and local permitting requirements; the ability to compile pre-specified information in a single application; deadlines that structure the approval process and result in certification or denial within a predictable and reasonable period of time; containment and predictability of costs due to reduced time and

169. See Solar Energy Standards Act, FLA. STAT. § 377.705 (2009) (creating the Florida Solar Energy Center (FSEC)). FSEC also certifies solar thermal systems. For information about the FSEC and its work, see FLA. SOLAR ENERGY CTR., http://www.fsec.ucf.edu (last visited Oct. 10, 2010).

170. See FLA. STAT. $\$ 377.703(2)$ (h) (listing these directives among others).

171. As of this writing, the Commission is still quite new and has yet to complete all of the duties identified, for which no deadline is specified in statute. For details on its activities, see FLA. ENERGY \& CLIMATE COMM'N, http://myfloridaclimate.com/climate_quick_links/ florida_energy_climate_commission (last visited Feb. 1, 2010).

172. In the interest of focus, this Part does not address in any depth the financing barrier to widespread deployment of rooftop PV, which affects whether a system will be installed, but does not directly implicate siting considerations. Financing is, however, a significant non-regulatory barrier to individual property owners' purchase of solar systems, to which a number of policy approaches are designed to respond, including rebates, tax credits, feed-in tariffs, propertyassessed clean energy (PACE) financing, and solar services agreements. See INTERSTATE Renewable ENERGy COUNCIL, 2009 UPDATE AND TRENDS 1-6, 30 (2009); see also DSIRE, supra note 5 (featuring state-by-state listing of adopted financing policies). 
money spent in the permitting process and legal challenges; certification for the life of the facility; and the possibility of preemption of local land use authority. Until this year, siting ground-mounted PV or other facilities smaller than $75 \mathrm{MW}$ required local land use approval pursuant to the GMA, with other permits obtained separately. It was a workable process, applicable to land use proposals of all kinds around the state, but was not the "efficient, simplified, centrally coordinated, one-stop licensing process" of the Siting Act. ${ }^{173}$ These differences begged the question of whether renewable energy projects are subject to regulatory disadvantage, when they so commonly generate less than $75 \mathrm{MW}$. It is important to note that any disparity affects only non-utility developers, because utilities can elect to proceed under the Siting Act. ${ }^{174}$ Could exclusion from the Siting Act function as an inverse regulatory barrier to smaller non-utility renewable projects relative to large-scale projects that qualify ${ }^{175}$

There is no single answer to this question, though the 2010 Legislature clearly considered it important. On the one hand, permitting requirements for smaller, non-polluting renewable facilities may not be particularly onerous. If siting for a project is considered appropriate locally-that is, if a site is selected with minimal environmental and community impacts and the facility itself is fairly small-the Siting Act process might be overkill. Arguably, for example, the need determination from the PSC would be an excessive prerequisite. But for other projects, such as biomass plants with extensive permitting requirements, or greenfield projects which might face opposition or permitting hurdles based on environmental impacts, the inability to streamline certification through the Siting Act process is a potential disadvantage. Every proposal is unique, but the closer to $75 \mathrm{MW}$ a project is, and the more it will pollute, the more likely it is that access to Siting Act benefits would be desirable. Viewed solely from the perspective of a goal to promote electricity from renewable resources, regulatory barriers to siting renewable energy should be removed. This is the clear objective of the

173. See FLA. STAT. $\$ 403.510(3)$ (2009).

174. See FLA. STAT. \& 403.506(1). The "applicant" can elect to apply for certification under the Siting Act, but the definition of "applicant" can only be an "electric utility." $\$ 403.503(5)$.

175. For a useful visual aide providing perspective on the regulatory simplicity accorded to Siting Act plants compared with lower than $75 \mathrm{MW}$ power plants, see Siting Coordination Office, General Overview of Regulations for Renewable Energy Facilities in Florida, DEP'T ENVTL. PROT., http://www.dep.state.fl.us/siting/files/renew_resource_permitting.pdf (last visited Oct. 16, 2010). See also TRC ET AL., MASS. EXEC. OFFICE OF ENERGY \& ENVTL. AFFAIRS, RENEWABLE ENERGY SITING STUDY E-3 (2009) (observing in the context of onshore wind permitting that the Massachusetts Energy Facilities Siting Board "only has authority to review generation facilities larger than $100 \mathrm{MW}$," which "has the effect of excluding most wind energy projects, as they are typically much smaller than $100 \mathrm{MW}$," and stating that "the results appear to show that small wind projects not eligible for [Siting Board] review can be subject to more delay than larger fossil fuel projects which can qualify for [Siting Board] review"). 
new expedited permitting provisions for renewable energy facilities. How to remove barriers without harmful effects can present a challenge, however. Advocates of land conservation or environmental justice, ${ }^{176}$ for example, will be wary of regulatory changes that could have the effect of authorizing greenfield or polluting projects more easily, even if the status quo made some renewable projects more difficult to site. ${ }^{177}$ These concerns underscore the importance of careful design in any regulatory effort to facilitate siting. For present purposes, the point is simply to highlight how the regulatory advantages to one category of power plants - large, mostly fossil fuel and nuclear power plants-can operate as a regulatory disadvantage to another, like renewable energy projects that are categorically less likely to trigger the Siting Act. The revised expedited permitting law ameliorates some of the key differences between the Siting Act and GMA. Namely, state agency coordination, clearer timetables for review, and limited post-approval litigation are now available to smaller facilities. ${ }^{178}$ It will be some time, however, before we can discern the significance of the Siting Act's ultimate state authority over land use compared with full retention of local control over small facility siting.

While the size threshold excludes smaller projects, the Siting Act has an embedded regulatory barrier of particular importance for large-scale renewable energy siting. As noted in Part II, a determination of need from the PSC is a prerequisite for obtaining Siting Act certification. Only a Siting Act "applicant" can request a determination of need. ${ }^{179}$ In Tampa Electric Co. v. Garcia, the Florida Supreme Court interpreted "applicant" narrowly to include only "Florida regulated utilities" that "provide electrical service to their Florida customers at retail rates." ${ }^{180}$ In that case, an out-of-state utility, Duke Energy, sought a joint need determination for a $514 \mathrm{MW}$ power plant with the Utilities Commission of New Smyrna

176. The U.S. Environmental Protection Agency defines environmental justice as "the fair treatment and meaningful involvement of all people regardless of race, color, national origin, or income with respect to the development, implementation, and enforcement of environmental laws, regulations, and policies." Environmental Justice, U.S. ENVTL. PROT. AGENCY, http:/www.epa.gov/environmentaljustice (last visited Nov. 1, 2010).

177. From these perspectives, many of the Siting Act's "benefits" may be problematic, such as the provisions allowing local land use preemption, $\S 403.508(f)$; Siting Board authority to alter non-procedural permit requirements, $\S 403.511(1)(b)$; and binding agreements on information to be provided in an application, to the extent this hamstrings the DEP or other agencies from seeking important information subsequently in the review process, $\S 403.5063$. Likewise, a summary administrative hearing for all comprehensive plan amendments related to renewable energy facilities, as provided in the new expedited permitting provisions, $\$ 403.973$, clearly favors energy developers over project or site opponents. A full public interest critique of the Siting Act is, however, outside the scope of this paper.

178. See full discussion on Florida's current siting scheme supra Part II.

179. See Fla. STAT. \$ 403.503(4) (2009).

180. Tampa Elec. Co. v. Garcia, 767 So. 2d 428, 435 (Fla. 2000) (citing FlA. STAT. § 403.503(13) (1991)). 
Beach. ${ }^{181}$ New Smyrna Beach had a contract for $30 \mathrm{MW}$ of the electricity generated from the plant, and the rest was intended to be sold wholesale to serve a general need for power in the state. The court held that the PSC lacked jurisdiction to grant a determination because the proposed power plant was not owned and operated by a Florida retail utility regulated by the PSC, and the plant's capacity was not fully committed to be sold to a Florida retail utility regulated by the PSC. ${ }^{182}$

The Tampa Electric opinion has been criticized as a strained reading of the statute ${ }^{183}$ and for constraining wholesale competition in electricity markets, potentially in violation of the Dormant Commerce Clause. ${ }^{184}$ Nonetheless, the case is controlling, ${ }^{185}$ and the legislative provisions at issue have not been amended in response to the holding. The case implicates renewable energy because, as the renewable energy market changes and evolves, an increasing number of large-scale renewable energy developers are national firms that operate as independent power producers in multiple states. ${ }^{186}$ The Siting Act bars such firms from siting large-scale projects in Florida without a Florida retail utility willing to apply jointly for a siting certification and commit to the full generation capacity of the proposed plant. By limiting who can site a facility in Florida, the Siting Act plays a role in insulating Florida utilities from outof-state competition, including non-utility renewable energy firms.

\section{b. Other Siting Considerations}

Power generation using solar PV offers three key benefits: no air pollution, no water consumption, and no waste. ${ }^{187} \mathrm{~A}$ ground-mounted

181. Duke Energy applied as an exempt wholesale generator, or independent power producer that generates and sells electricity in wholesale markets regulated by FERC, not the states. See Tampa Elec., 767 So. $2 \mathrm{~d}$ at 430.

182. Tampa Elec., 767 So. 2d, at 433-34 (relying on Nassau Power Corp. v. Beard, 601 So. 2d 1175 (Fla. 1992) (holding that a non-utility generator was not a proper applicant under the Siting Act).

183. Tampa Elec., 767 So. 2 d at 436 (Anstead, J., dissenting).

184. The Commerce Clause empowers Congress to regulate interstate commerce. See U.S. CONST. art. I, $\$ 8, \mathrm{cl}$. 3 . In the absence of federal regulation, states may regulate "so long as they act within the restraints imposed by the Commerce Clause itself"- that is, the Dormant Commerce Clause prohibits state regulation that creates an undue burden on interstate commerce. See Philadelphia v. New Jersey, 437 U.S. 617, 623 (1978). See generally Jeffrey S. Dennis, Federalism, Electric Industry Restructuring and the Dormant Commerce Clause: Tampa Electric Co. v. Garcia and State Restrictions on the Development of Merchant Power Plants, 43 NAT. RESOURCES J. 615 (2003).

185. The U.S. Supreme Court denied certiorari. See Utils. Comm'n v. Tampa Elec. Co., 532 U.S. 905 (2001).

186. To be clear, the limitation depends on the status of the generator, not the type of facility proposed. Duke and New Smyrna Beach were proposing a natural gas-fired plant.

187. These claims for solar power can only be made in connection with power generation. The manufacture of solar PV panels, by contrast, results in significant pollution, and disposal of 
array can, however, require a fair amount of space. It can take five or more acres to produce $1 \mathrm{MW}$ of electricity, with "[t]he actual land requirements ... driven by both the solar resource and the configuration of the PV system."188 Although the National Renewable Energy Laboratory (NREL) estimates that "only $0.4 \%$ of the area of the United States" would be needed "to supply all of our nation's electricity using [groundmounted] PV," the obvious land use concern for large-scale solar arrays is consumption of natural land serving as wildlife habitat or providing other ecosystem services. ${ }^{189}$ FPL's newly operative solar PV facility in Desoto County, for example, used 180 previously undeveloped acres for $25 \mathrm{MW}$ of generation capacity. ${ }^{190}$ The $100 \mathrm{MW}$ facility planned for the Kennedy Space Center will use 500 acres of former citrus groves, and a $10 \mathrm{MW}$ facility under construction requires 60 acres to be cleared. ${ }^{191}$

To determine Florida's land availability for ground-mounted PV, the Navigant study relied on land use data from the Florida water management districts. The analysis identified several land use typesabandoned mining lands, open land, inactive land with street pattern but no structures, other open lands, rural, and barren land - then screened for wetlands, forests, developed land, urban areas, recreational and farm land, preserved areas, and historic sink holes. ${ }^{192}$ Under this framework, 389,000 acres, or approximately 600 square miles, was the resulting "available" land projection for ground-mounted PV. ${ }^{193}$ The study concluded that siting solar PV on "available" land could support a technical potential for $32,000 \mathrm{MW}$ of capacity in 2009 , increasing with efficiency improvements to $37,000 \mathrm{MW}$ by $2020 .{ }^{194}$

One could criticize aspects of the study's methodology, and certainly every proposed site is unique, but the analysis demonstrates how even local policy instruments based on targeted geographic screening can help guide renewable energy projects away from undeveloped natural areas. It

out-of-service panels is no small waste concern. See SILICON VALLEY TOxICS COALITION, supra note 18 (raising concerns over toxic byproducts of PV manufacture and disposal).

188. Paul Denholm \& Robert Margolis, Impacts of Array Configuration on Land-Use Requirements for Large-Scale Photovoltaic Deployment in the United States 1 (Nat'l Renewable Energy Lab., Conference Paper No. NREL/CP-670-42971, May 3-8, 2008), available at http://www.nrel.

gov/docs/fy08osti/42971.pdf.

189. See PV FAQs: How much land will PV need to supply our electricity?, NAT'L RENEWABLE ENERGY LABORATORY,

http://www1.eere.energy.gov/solar/pdfs/35097.pdf (last visited Sept. 1, 2010).

190. See generally DeSoto Next Generation Solar Energy Center FAQs, FLA. POWER \& LIGHT, http://www.fpl.com/environment/solar/desoto_faq.shtml (last visited Nov. 1, 2009).

191. See Jim Waymer, Solar Energy Plant at KSC Generates Jobs, FLORIDATODAY.COM (Nov. 20, 2009), http://pqasb.pqarchiver.com/floridatoday/access/1905930421.html?FMT = ABS\&amp;date $=$ Nov $+20 \% 2 \mathrm{C}+2009$.

192. See NAVIGANT, supra note 57 , at 35 .

193. See id.

194. See id. 
is important to emphasize, of course, that the screening limitations used in the study may or may not actually exist on the ground. In other words, many sites deemed theoretically "unavailable" may in fact be future power plant sites. It is never surprising in Florida for wetlands to be filled or farm land converted to other uses. Solar projects, however, can be excellent uses for despoiled or underused developed sites, even in close proximity to populated areas, because of their zero-emission, waste-free power generation.

The U.S. Environmental Protection Agency (EPA) has recognized this potential and launched a Re-Powering America's Land Initiative to promote abandoned mining sites, closed landfills, and other contaminated properties for renewable energy siting. ${ }^{195}$ In a study commissioned by the EPA, the NREL conducted a geographic screening of "limbo lands" as sites for renewable energy generating facilities: former Superfund sites, landfills, brownfields, ${ }^{196}$ abandoned mine lands, former industrial sites, and certain government installations that are considered "ready for redevelopment." ${ }^{\text {"197 }}$ In total, nationwide, the study identified 737 limbo land sites with potential for renewable energy development. ${ }^{198} \mathrm{PV}$ solar arrays are considered suitable for any limbo land site because the ubiquitous solar resource is adequate across the United States. ${ }^{199}$ At the same time, limbo lands often offer close proximity to existing transmission infrastructure, facilitating the supply of power to the grid. $^{200}$ The NREL selected Florida as a case study, on brownfields site screening and identified 119 sites suitable for PV, ranging from one acre to over five thousand acres in size. ${ }^{201}$

195. See Siting Clean and Renewable Energy on Contaminated and Mining Sites: Fact Sheet, U.S. ENVTL. PROT. AGENCY, http://www.epa.gov/renewableenergyland/docs/repower_ contaminated_land_factsheet.pdf (last visited Dec. 1, 2009). The site provides interactive mapping tools and other resources for planners and project developers with an interest in siting on potentially contaminated properties. See also NAT'L RENEWABLE ENERGY LABORATORY, CONVERTING LIMBO LANDS TO ENERGY-GENERATING STATIONS: RENEWABLE ENERGY TECHNOLOGIES ON UNDERUSED, FORMERLY CONTAMINATED SITES (2007), available at http://www.nrel.gov/docs/fy08osti/41522.pdf.

196. The term "brownfield site" refers to "real property, the expansion, redevelopment, or reuse of which may be complicated by the presence or potential presence of a hazardous substance, pollutant, or contaminant." 42 U.S.C. § 9601(39)(A) (2006); see also FLA. STAT. § 376.79(3) (2009) (defining "brownfield sites" as "real property, the expansion, redevelopment, or reuse of which may be complicated by actual or perceived environmental contamination").

197. See NAT'L RENEWABLE ENERGY LABORATORY, supra note 195, at 1-2.

198. See id. at 7.

199. See id. at 16.

200. See id. at 3.

201. See id. at 26. At least 1 closed landfill in Florida is already the site of a small 1200-panel solar array, with the rest of the 450-acre site developed as a recreational park. See, e.g., Zac Anderson, Sarasota's Solar Revolution, HERALD TRIB., Feb. 11, 2008, at A1. For information about other completed renewable energy projects at landfills, see e.g., Examples of Completed Renewable Energy Projects at Landfills, MASS. DEP'T ENVTL. PROT., http://www.mass.gov/dep/energy/fflinks.htm (last visited Nov. 1, 2009). 
The regulatory context for permitting a project at a closed landfill ${ }^{202}$ or other brownfield site raises layers of complexity that will not be present at other sites. There are liability considerations for site owners, renewable energy developers, and regulators, and site work must ensure that known or potential contamination is not disturbed. ${ }^{203}$ From a siting standpoint, however, the regulatory hurdles are likely to be few. A land use change via comprehensive plan amendment will not be necessary in many cases, given that landfills and brownfields are typically already designated for industrial uses. This would ease approval whether the project was reviewed via the land use consistency determination under the Siting Act or at the local level under the GMA. If a land use change is required, it may qualify for an exception to the twice-annual plan amendment limitation available for redevelopment of designated brownfield areas. ${ }^{204}$ Roads and grid interconnection are likely to be more accessible than for greenfield sites, and clean solar projects can refresh a site that may have been vacant or otherwise abandoned, burdening the aesthetic and property values of the surrounding community. ${ }^{205}$ Unless another use is environmentally viable and clearly preferable for community well-being, such as a badly needed recreational or commercial facility in proximity to residential neighborhoods, solar siting may serve environmental justice goals well by bringing a non-polluting enterprise to a brownfield site.

202. The administrative rule applicable to solid waste management facilities does not include language regarding potential land uses for closed landfills. See FLA. ADMIN. CODE ANN. r. 62-701.610(7) (2009). But the DEP has provided permitting and construction guidance for redeveloping such sites. See Fla. DEP'T OF ENVTL. Prot., GUIDANCE FOR DisTURBANCE AND USE OF OLD CLOSED LANDFILLS OR WASTE DISPOSAL AREAS IN FLORIDA (2009).

203. An in depth discussion of brownfields law is beyond the scope of this Article. In Florida, the Brownfields Redevelopment Act (BRA) governs the reuse of brownfield sites. FLA. STAT. $\$ \$ 376.77-84$ (2009). The BRA is administered by local governments, which designate brownfield areas, see $\$ 376.80$, with oversight from DEP, see $\$ \S 376.79(7), .80$. The BRA provides financial, regulatory, and technical assistance to encourage voluntarily cleanup of contaminated sites by responsible parties, and clarifies liability issues for future developers and lenders. See $\$$ 376.84. For assessments of the BRA, see Carolyn Haslam, Urban Redevelopment and Contaminated Land: Lessons from Florida's Brownfield Redevelopment Program, 11 ENVTL. PRACTICE 153 (2009); Tara Burns Koch, Comment, Betting on Brownfields-Does Florida's Brownfields Redevelopment Act Transform Liability into Opportunity?, 28 STETSON L. REV. 171 (1998) (discussing the BRA in the context of related federal law). See also Steven Ferrey, Smart Brownfield Redevelopment for the 21st Century, Symposium Article: Converting Brownfield Environmental Negatives into Energy Positives, 34 B.C. ENVTL. AFF. L. REV. 417, 436 (2007) (discussing reuse of brownfields for energy projects, with focus on landfill gas electrical plants).

204. See FlA. STAT. $\$ 163.3187(1)(\mathrm{g})(2009)$.

205. See FLA. STAT. $\S 376.78(2)$ (2009) (stating legislative recognition that "[t]he abandonment or underuse of brownfield sites ... results in the inefficient use of public facilities and services, as well as land and other natural resources, extends conditions of blight in local communities, and contributes to concerns about environmental equity and the distribution of environmental risks across population groups"). 


\section{Rooftop Photovoltaic Panels}

\section{a. Regulatory Context}

Rooftop PV is prototypical distributed generation (DG)-power generated at many geographically dispersed sites to serve mostly onsite electricity needs. ${ }^{206}$ This model contrasts with centralized utility-scale facilities, which generate power for transmission and distribution to many consumers. Rooftop systems are commonly regarded as conservation measures, simply reducing individual customers' electricity bills by reducing the amount of electricity they purchase from their utility. Still, these systems generate power; as capacity from DG increases, the conservation characterization may be less fitting.

Across the country, regulation has complicated siting rooftop solar in two primary respects: insufficient regulatory support for interconnection to the electrical grid (a basic siting prerequisite), and legal and regulatory barriers to the physical installation of solar power systems.

Interconnection is the interface between the electrical grid and a rooftop PV system, whether residential, commercial, or industrial. ${ }^{207}$ Rooftop solar panels do not have to be connected to the grid, but this is typically how systems are installed. ${ }^{208}$ Absent uniform and simplified procedures, both technical and legal, "plugging in" to the grid can be so time-consuming, difficult, and expensive that it hinders siting new, and especially small, systems. ${ }^{209}$

In 2008, at the direction of the Legislature, the PSC adopted a rule to address this problem in Florida. ${ }^{210}$ The rule requires investor-owned

206. Small-scale wind turbines and onsite combined heat and power systems are other common modes of DG.

207. See Network for New Energy Choices et al., Freeing the Grid: Best and WORST PRACTICES IN STATE NET METERING POLICIES AND INTERCONNECTION STANDARDS 19 (2009), available at http://www.newenergychoices.org/uploads/FreeingTheGrid2008 report.pdf. Interconnection also refers to the grid interface with other forms of decentralized electricity generation, including independent power producers that sell electricity to utilities. For interconnection purposes, renewable energy facilities are treated like other small power producers under a separate administrative rule. See FLA. ADMIN. CODE ANN. r. 17.087-.220 (2009).

208. See INTERSTATE RENEWABLE ENERGy COUNCIL, supra note 172, at 9-10 (identifying grid-connected installations as the largest growth sector for PV, with 86 percent of 2008 installed capacity connected to the grid, including rooftop and ground-mounted systems). For an example of an off-grid, zero emissions house, see Energy \& Sustainability Ctr., Off-Grid Zero Emission Buildings, FLA. ST. UNIV., http://esc.fsu.edu/ogzeb.html (last visited Oct. 10, 2010) (detailing Florida State University's Energy and Sustainability Center showcase model).

209. See NETWORK FOR NEW ENERGY CHOICES ET AL., supra note 207, at 5.

210. See Fla. AdMIN. CODE ANN. r. 25-6.065 (2009); see also FlA. STAT. \$ 366.91(5) (2009) (requiring the PSC to establish interconnection requirements for customer-owned renewable generation, including but not limited to solar, and authorizing rulemaking). Net metering, a measure designed to encourage distributed generation, allows customers' electric meters to track 
utilities to develop standardized interconnection agreements "for expedited interconnection of customer-owned renewable generation, up to $2 \mathrm{MW}$."211 In addition to requiring standardized agreements, the rule eases interconnection by specifying technical requirements and limiting utilities' power to require extra equipment or charge fees to generating customers. $^{212}$

Adopting the interconnection rule was an important step in supporting distributed solar energy, but the rule has weaknesses. First, the interconnection rule applies only to investor-owned utilities; so, for example, to FPL, but not the City of Tallahassee Utilities. The Legislature directed municipal electric utilities and rural electric cooperatives to develop standardized agreements independently, but they are not subject to PSC review and approval. ${ }^{213}$ There remains potential, then, for barriers to exist in areas served by these utilities, in the form of fees or onerous technical or administrative requirements. ${ }^{214}$ Regulatory variation from jurisdiction to jurisdiction remains a potential time and cost barrier, as system installers find themselves navigating multiple application and interconnection requirements, even in a small geographic area. ${ }^{215}$ The $2 \mathrm{MW}$ cap is limiting in that it does not accommodate "systems that are sized to meet even large on-site loads for such applications as hospitals, office parks, and college campuses." 216 For these reasons and others, the EPA has rated Florida "unfriendly" to distributed generation, compared with other states that have adopted interconnection standards. ${ }^{217}$ Likewise, Florida's rule received the grade

the energy their system produces, adjusting the meter accordingly to offset part or all of their utility electric bill. See FlA. STAT. $\$ 366.91(2)(c)(2009)$; FLA. ADMIN. CODE ANN. r. 25$6.025(2)$ (c) (2009).

211. Fla. ADMIN. CODE ANN. r. 25-6.065(3) (2009).

212. See Fla. Admin. Code AnN. r. 25-6.065(4)(d)-(f) (2009).

213. See FLA. STAT. \$ 366.91(5) (2009).

214. It can probably be assumed that the risk of intentional barriers is lower given the public ownership status of these utilities. Municipal electric utilities and rural electric cooperatives are not-for-profit entities. There are thirty-four municipal utilities in Florida, serving 25 percent of the state's population. They are typically governed by the local city or county commission or utility authority comprised of appointed or elected commissioners. There are fifteen electric distribution cooperatives and two generation and transmission cooperatives in Florida, operating in fifty-seven counties and serving over one million consumers. For information about Florida's municipal utilities, see Florida Public Power, FLA MUN. ELEC. Ass'N, http://www.public power.com (last visited Oct. 10, 2010). For information about Florida rural electric cooperatives, see FlA. ElEC. COOP. Ass'N, http://www.feca.com (last visited Oct. 10, 2010).

215. Personal Communication, Sustainable Tallahassee Solar Advocacy Meeting, Tallahassee, Florida (Jul. 2009) (roundtable discussion addressing barriers to local proliferation of rooftop solar PV).

216. DORIS ET AL., supra note 5, at 57.

217. See Established State Interconnection Standards: Assessment for DG Friendliness, U.S. ENVTL. PROT. AGENCY, http://www.epa.gov/chp/state-policy/interconnection.html (last visited Nov. 2009). 
of " $\mathrm{C}$ " in a report surveying and grading interconnection standards across the fifty states. ${ }^{218}$

While interconnection is a state-level and utility-based barrier, constraints on the physical installation of rooftop panels historically have been local. Common regulatory barriers to siting solar include private property restrictions, such as homeowners' association covenants or restrictions, and local governmental restrictions, such as building codes. ${ }^{219}$ Moreover, access to sunlight is essential for a functioning rooftop solar energy system. It follows that siting rooftop PV depends not just on the right to install a system in the first place, but also on the right to maintain access to sunlight once a system is installed.

In Florida, explicit statutory protections for solar access against public or private restriction have addressed some of the most common legal and regulatory barriers to siting rooftop PV. Florida law expressly prohibits a "governing body" from adopting any ordinance that limits the installation of on-site renewable energy devices. ${ }^{220}$ This goes so far, it would seem, as to preclude even historic preservation ordinancesanother common regulatory barrier to rooftop PV panels-from prohibiting the use of renewable energy devices. ${ }^{221}$ Private agreements, such as deed restrictions or covenants, may not be used in Florida to "prohibit or have the effect of prohibiting" the installation of renewable energy devices. ${ }^{222}$ Likewise, homeowners' associations and similar entities that would otherwise be in a position to review and approve or deny modifications to a property may not deny permission to install renewable energy devices. ${ }^{223}$ If rights under these laws are litigated, the prevailing party is entitled to attorneys' fees. ${ }^{224}$ Solar easements are specifically

218. NETWORK FOR NEW ENERGY CHOICES ET. AL., supra note 207, at 47. Florida received an "A" rating for its net metering rule. See id. at 47.

219. See Colleen McCann Kettles, Fla. Solar Energy Research and Educ., A COMPREHENSIVE REVIEW OF SOLAR ACCESS LAW IN THE UNITED STATES 1-6 (2008).

220. See FLA. STAT. § 163.04(1) (2009) ("Notwithstanding any provision of this chapter or other provision of general or special law, the adoption of an ordinance by a governing body, as those terms are defined in this chapter, which prohibits or has the effect of prohibiting the installation of solar collectors, clotheslines, or other energy devices based on renewable resources is expressly prohibited.") See §§ 163.3163(9), .3401(3) (2009) (defining "governing body").

221. Cf. Sara C. Bronin, The Quiet Revolution Revived: Sustainable Design, Land Use Regulation, and the States, 93 MiNN. L. REV. 231, 251 (2008) ("[S]olar panels seem to have retained their reputation for being undesirable aesthetically. Indeed, aesthetic review boards and historic preservation boards, which typically govern structures visible from a public way, regularly reject their installation. Unfortunately, to maximize sun exposure, panels must often be sited in locations at least partially visible from a public way. The solar panel example highlights the tension between the aesthetic concerns of design control boards and the energy-efficiency concerns of environmental advocates.") (internal citations omitted).

222. See $\$ 163.04(2)$.

223. See id. (with respect to residential dwellings and condominiums).

224. See id.; see also KETTLES, supra note 219 , at 7 . 
authorized between private parties as a means of protecting access to sunlight against obstruction. ${ }^{225}$

These provisions appear to protect the right to site rooftop PV fairly well, but it is unclear how effective they are in practice. There is no enforcement mechanism, and it can be extremely costly for an individual to litigate to protect against illegal private restrictions. ${ }^{226}$ The limits of the provisions make this a concern. Section 163.04 of Florida Statutes simply forbids regulation from "prohibiting" the operation of a renewable energy device, but this does not prevent a maze of redundancies, inconsistencies, and delays in the electrical or other permitting processes at the local level. ${ }^{227}$ Because permitting barriers of this kind do not prohibit rooftop PV, they can persist without contravening the statutory protection of solar rights. Similarly, a close reading makes clear that it is possible for an ordinance or association rule to allow the renewable energy devices as required by state law, but with limitations that affect their functioning. Non-governmental entities like homeowners' associations retain the right to determine the location of rooftop panels, but only so long as "such determination does not impair the effective operation of the solar collectors." 228 This leaves a gray area in which property owners may be unable to maximize the generation capacity of their system but have little recourse..$^{229}$

Finally, it is also important to recognize that the statute only goes so far. It does not, for example, ensure that access to sunlight for an installed system will be protected against shadows from new vegetation or structures on neighboring properties. ${ }^{230}$ Although solar easements can

225. See FLA. STAT. \& 704.07 (2009).

226. See KeTtLeS, supra note 219, at 6; see also Sara C. Bronin, Solar Rights, 89 B.U. L. REV. 1217, 1225-65 (2009) (discussing possible common law claims for seeking recognition of solar rights in court, including nuisance, prescriptive easements, and implied easements).

227. For a detailed discussion of local permitting barriers to siting distributed solar energy, see Damien PITt, Network for NEW ENERGy CHOICES, TAKING tHe Red TAPE OUT OF GREen POWER: How to OVERCOME PERMITTING ObSTACles to SMAll-SCAle DISTRIBUTED ENERGY 15-29 (2008).

228. $\$ 163.04(2)$ (with respect to residential dwellings and condominiums).

229. See City of Ormond Beach v. State, 426 So. 2d 1029, 1032 (Fla. Dist. Ct. App. 1983). The court reversed and remanded a case involving denial of a variance from local height restrictions for erection of a windmill on a residence, citing FLA. STAT. $\$ 163.225(3)$ (a), which "requires a showing that the variance requested is the minimum variance that will make possible the reasonable use of the structure. 'Reasonable use' should neither be the very best nor the very worst." The court reasoned that "'optimum' performance of the windmill . . . alone does not entitle petitioner to a variance. He may not be entitled to 'optimum' performance if something less than that produces satisfactory performance of the windmill." City of Ormond Beach, 426 So. $2 \mathrm{~d}$ at 1032.

230. At least one city, however, the City of Gainesville, even requires the removal or relocation of trees that prevent the installation of solar energy equipment. See GAINESVILLE, FLA., CODE OF ORDINANCES $\S \S 30.251, .254$ (used as model ordinance in KETTLES, supra note 219 , at 16). 
address this, neighbors cannot be forced to provide the easement. ${ }^{231}$ Like Florida, many states have explicitly authorized solar easements, but it is unclear how many such agreements are actually in place. ${ }^{232}$ As rooftop solar systems proliferate, we can expect to see the rights and liabilities associated with solar access better defined by the legislature and the courts. $^{233}$

\section{b. Other Siting Considerations}

Most of the siting considerations for centralized energy projects are irrelevant for rooftop solar. Plainly, no terrestrial power generation can top it in terms of land use efficiency, as the panels are incorporated into existing structures on already developed land, with few geographic restrictions. The systems do not require water, so proximity to water resources is unnecessary. They produce no air pollutants or waste when generating electricity, making it safe to site rooftop solar in and around populated areas. ${ }^{234}$ Despite the regulatory inconsistencies and barriers discussed above, with no environmental review or land use change needed, siting rooftop solar takes little time by comparison to centralized energy projects.

As system installations increase nationwide, however, grid integration looms as a siting barrier for rooftop PV. This is not so much a site-by-site barrier, like interconnection can be, but a barrier to how much DG the grid can support. Solar (and wind) energy is variable, meaning these resources produce power only intermittently. In 2007, the U.S. Department of Energy launched a renewable systems interconnection study, noting, "concerns about potential impacts on operation and stability of the electricity grid may create barriers to further expansion." 235 The study found that grid-related barriers are likely to inhibit distributed generation sooner than previously expected, based

231. See KETTLES, supra note 219 , at 6 .

232. See Bronin, supra note 226 , at 1229 (concluding that this "legislative cheerleading' has not, however, borne much fruit" in light of the fact that not a single case could be found dealing with express solar easements, suggesting that they are rarely executed).

233. For an overview of solar access laws and assessment of options for refining the contours of legal rights to solar access, see Troy A. Rule, Shadows on the Cathedral: Solar Access Laws in a Different Light, 2010 U. ILL. L. REV. (forthcoming 2010); Adrian J. Bradbrook, Future Directions in Solar Access Protection, 19 ENVTL. L. 167 (1988) (evaluating solar access controls and attempting to formulate new direction for the law to take). For a proposal to modernize solar rights to match the need for onsite renewable energy generation, see Sara C. Bronin, Modern Lights, 80 U. COLO. L. REV. 881 (2009).

234. Again, there are significant concerns about waste by-products in the PV manufacturing process, however, raising questions about life-cycle sustainability of solar energy. See generally SILICON VALLEY TOXICS COALITION, supra note 18.

235. NAT'L RENEWABLE ENERGY LABORATORY, RENEWABLE SySTEMS INTERCONNECTION 1 (2008). 
on market and policy advancements in support of onsite solar energy. ${ }^{236}$ Existing distribution systems were designed for centralized power transmission and have limited capacity for reverse flows of electricity from distributed sites. ${ }^{237}$ The study concluded that it is "clearly time to begin planning for the integration of significant quantities of distributed renewable energy onto the electricity grid."238 It is still uncertain just how much variability existing infrastructure can absorb, but there seems to be general agreement that significant potential for solar energy cannot be realized without modernizing the grid. ${ }^{239}$

Grid capacity is not yet a barrier to rooftop solar in Florida, but it is a technical problem that will become a policy problem and siting barrier if grid limitations begin to impede new system installations. According to the Florida Solar Energy Research and Education Foundation, solar electric and water heater system installations together increased more than 40 percent in response to a state rebate program, ${ }^{240}$ but there is still significant room to grow: approximately 27 percent of residential and 60 percent of commercial roof space is considered "available" for PV installations. ${ }^{241}$ It may well be that grid capacity will keep pace with solar growth, but it is too early to know. Grid integration research is ongoing at the federal level, and Florida universities have received a federal grant to support a five-year research plan directly concerning integration of solar energy into the grid. ${ }^{242}$

A second consideration that implicates siting is who can own a rooftop solar system. Florida law recognizes "customer-owned renewable generation," but there is presently no regulatory structure to facilitate utility ownership of customer-sited renewable energy. ${ }^{243}$ Elsewhere, this is beginning to change. As Professor Michael Dworkin recently observed, "the relationship between the utility and distributed energy resources is

236. See id. at 1.

237. See id. at 8 .

238. Id. at 1 .

239. See, e.g., Paul Komor, Pew CTr. On Global Climate Change, Wind and Solar ELECTRICITY: CHALLENGES AND OPPORTUNITIES 24 (2009). For an in depth discussion of the legal and regulatory issues that pertain to grid modernization to accommodate renewable energy, see Steven Ferrey, Restructuring a Green Grid: Legal Challenges to Accommodate New Renewable Energy Infrastructure, 39 ENVTL. L. 977 (2009).

240. See Fla. SOlAR ENERGY RESEARCH AND EDUC. FOUND., http://www.flaseref.org/ generalFactsInfo.html (last visited Nov. 2009).

241. See NAVIGANT, supra note 57, at 38-39 (accounting for functional constraints from shading, structural adequacy, orientation, and roof pitch).

242. Regarding federal research, see NAT'L RENEWABLE ENERGY LABORATORY, RENEWABLE SYSTEMS INTERCONNECTION: EXECUTIVE SUMMARY (2008), available at http:/www.nrel.gov/docs/fy08osti/42292.pdf (last visited Oct. 17, 2010). Regarding Florida's grant, see \$3.6 Million Federal Grant to Address Integrating Solar Energy into Electric Grid, FLA. ST. UNIV. (Oct. 20, 2009, 1:12 PM), http://www.fsu.com/News-Archive/2009/October/3.6-MillionFederal-Grant-to-Address-Integrating-Solar-Energy-into-Electric-Grid.

243. See FlA. ADMIN. CODE ANN. r. 25-6.065(2)(a) (2009). 
evolving."244 The implication for renewable energy siting is the potential for a far greater supply of rooftop sites coming available for power generation. Utility ownership of these resources is a fairly new concept that addresses two issues: the financing barrier to installation by individual property owners, ${ }^{245}$ and, more importantly, regulated utilities' profit imperative to obstruct widespread DG. ${ }^{246}$ In Florida, as in most states, utility profits have not been decoupled from electricity sales. ${ }^{247}$ Florida properties generating electricity onsite reduce consumption of utility-generated electricity. For this reason, utilities have typically perceived DG "as a third-party-owned asset that cuts into the rate base and adds a complicated and unprofitable layer to the system."248

According to Professor Dworkin, policies that support utilities' ownership of PV assets on customer property could reverse that disincentive and yield a number of benefits. This model could rapidly increase the number of "available" sites for PV installation, with utilities in a position to consider the most beneficial sites and system sizes in light of grid management concerns. ${ }^{249}$ It would also provide a strong incentive for utilities to perfect and streamline interconnection and advance grid updates to accommodate variable and two-way flow. ${ }^{250}$ The NREL is pursuing research into how best to assist state agencies and utilities with pilot programs for so-called "second-generation business models," including utility shared or sole ownership of DG. ${ }^{251}$

Professor Dworkin's analysis concludes that there are "no major obstacles in the path of utilities when it comes to rate basing distributed PV."252 At present, though, utility ownership of customer-sited PV does not fit into most states' existing regulatory frameworks for DG or utility cost recovery. Florida's 2-MW-or-less interconnection rule is specifically designed "to promote the development of small customer-owned

244. Michael Dworkin, SOlar EleC. POWER Ass'N, RePort No. 04-09: Distributed PHOTOVOLTAIC GENERATION FOR REGULATED UTILITIES 11 (2009).

245. See DSIRE, supra note 5, for searchable database of financial incentives and benefits aimed at addressing this well-recognized barrier.

246. See generally DWORKIN, supra note 244. This concept is one of several business models developed by the Solar Electric Power Association to overcome utility resistance to distributed solar energy. See SOLAR EleC. POWER Ass'N, UTILITY SOlAR BUSINESS MOdELS (2008).

247. Florida has studied but not acted upon the decoupling concept. See FLA. PUB. SERV. COMM'N, REPORT TO THE Legislature ON UTILITY ReVENUE DeCOUPLiNG (2008) (as required by 2008 Fla. Laws ch. 227, s. 114 (H.B. 7135)).

248. Steven Andersen, The Future Looks Bright for Distributed PV, 147 PUB. UTIL. FoRT. 66, 68 (Sept. 1, 2009).

249. See DWORKIN, supra note 244, at 12.

250. See id. at 12, 21. Other benefits, unrelated to siting, might include easier aggregation of renewable energy credits for use in meeting an RPS, where applicable, or selling credits to another utility. See id.

251. See Nat'L Renewable Energy laboratory, Renewable Systems INTERCONNECTION 13 (2008).

252. DWORKIN, supra note 244 , at 23. 
renewable generation." 253 The rule defines this term to mean "an electric generation system located on a customer's premises that is primarily intended to offset part or all of the customer's electricity requirements with renewable energy." 254 By contrast, under a utility ownership model, the electricity generated at the customer-owned site simply feeds back into the grid; net metering does not apply and the PV system "has no effect on the customer's electricity consumption bill ... the location becomes merely a site host."255 The rule defines "customer-owned renewable generation" expansively to include situations in which customers are "contracting for the purchase, lease, operation or maintenance of an onsite renewable generation system with a third-party under terms and conditions that do not include the retail purchase of electricity from the third party."256 The third-party non-utility ownership model is also fairly new and has provided a helpful financing option for some customers, particularly in the commercial and industrial sectors. ${ }^{257}$ It is clear from the rule's caveat, however, that third parties are not intended to be characterized (and regulated) as utilities, which are the only entities authorized to sell retail electricity in the state. ${ }^{258}$ It follows that only customer or non-utility third party ownership is covered by the rule. A utility ownership model could complement the existing customer/thirdparty-owned model for distributed generation, but a separate or substantially modified rule would be needed to facilitate and structure utility siting of rooftop PV on customer property, including terms for a lease or siting fee. ${ }^{259}$

Even more important than a specialized rule, however, would be clear statutory validation of rate basing for customer-sited PV. Utility

253. Fla. Admin. CODE ANN. r. 25-6.065(1) (2009) (emphasis added). No distinction is made between residential and commercial or industrial customers, though the rule makes some distinctions based on generation capacity. See id.

254. Fla. Admin. Code ANN. r. 25-6.065(2)(a) (emphasis added).

255. DWORKIN, supra note 244, at 23; see also Andersen, supra note 248 , at 70.

256. Fla. AdMin. CODE ANN. r. 25-6.065(2)(a).

257. See NETWORK FOR NEW ENERGY CHOICES ET AL., supra note 207, at 89; see also Raymond Marshall, A Framework for Energy Independence via Solar Hosting Farms, 36 ECOLOGY L. CURRENTS 212 (2009), http://elq.typepad.com/currents/2009/08/currents36-10marshall-2009-0726.html.

258. See PW Ventures, Inc. v. Nicholas, 533 So. 2d 281, 284 (Fla. 1988) (holding that retail sale of electricity to customers subjects the seller to regulation as a public utility under state law); see also Interconnection and Net Metering of Customer-Owned Renewable Generation, Pub. Serv. Comm'n Docket No. 070674-EI, at 7-8 (proposed Dec. 7, 2007) (to be codified at FLA. ADMIN. CODE ANN. r. 25-6.065(1)) (discussing the need to preserve non-utility status for thirdparty owners in drafting of the rule, pursuant to $P W$ Ventures); INTERSTATE RENEWABLE ENERGY COUNCIL, 2009 UPDATE AND TRENDS 14 (2009) (cautioning against defining third parties as utilities, to avoid problems with access to the federal investment tax credit for nonutility third party owners of solar systems).

259. Duke Energy "will pay customers a monthly rental fee based on the size of the installation and the amount of energy generated." Andersen, supra note 248, at 70. 
assets in capital property for generation, transmission, and distribution are its "rate base" on which it is authorized by law to earn a return for investors via rates charged for electricity to customers. ${ }^{260}$ Without clear statutory direction, it is an open question whether investment in rooftop systems would be treated as eligible for inclusion in rates or other cost recovery. In assessing utility requests for rate basing, Florida law employs a "prudence" and "used and useful" standard; the PSC has authority to set "fair, just, and reasonable rates" for electric utilities based on "the actual legitimate costs" of utility property if they represent investments made "honestly and prudently" and are "actually used and useful in the public service." ${ }^{\text {261 }}$ A utility promoting such a program would have to make a case to the PSC that investment in PV on leased rooftop space was a prudent expense, and that the component assets are "used and useful." "262 Arguably, rate-basing should apply to distributed energy assets according to the same principles that apply to centralized generation assets, with the analysis turning on details of the specific business model adopted. ${ }^{263}$

Utility petitions for costs associated with PV assets are not unprecedented. In a recent determination, the North Carolina Utilities Commission approved an application for cost recovery of customer-sited PV using similar standards to Florida's own. ${ }^{264}$ Duke Energy sought authorization to construct $10 \mathrm{MW}$ of solar PV generation, including rooftop installations on large commercial and industrial buildings ranging from $500 \mathrm{~kW}$ to $3 \mathrm{MW}$, as well as small-scale facilities on residential rooftops, ranging from 1.5 to $5 \mathrm{~kW}$ in capacity. ${ }^{265}$ Duke tied its argument for recovery of costs to the state's RPS, citing the new installations' role in providing solar energy, but also the fact that ownership would enable Duke "to develop competency as an owner of solar renewable assets, to leverage volume purchases, to build relationships with solar PV developers, manufacturers and installers to gain experience with the installation and operation of various types of solar distributed generation facilities, and to evaluate the impact of such facilities on its electric

260. See DWORKIN, supra note 244, at 6; SANFORD V. BERG, PUB. UTIL. RESEARCH CTR., UNIV. OF. FLA., GLOSSARY FOR THE BODY OF KNOWLEDGE ON THE REGULATION OF UTILITY INFRASTRUCTURE AND SERVICES 67 (2005), available at http:/www.regulation bodyofknowledge.org.

261. FLA. STAT. $\$ 366.06(1)$ (2009).

262. Dworkin, supra note 244, at 18-19; see Citizens of Florida v. Fla. Pub. Serv. Comm'n, 425 So. $2 \mathrm{~d} 534$ (Fla. 1982) (reviewing used-and-useful analysis by PSC under $\$ 366.06$ ).

263. See DWORKIN, supra note 244 , at $19-22$ (discussing potential benefits that justify rate basing utility ownership of customer-sited PV). The policy implications and incentives created by rate structures and cost recovery mechanisms are complex and critically important issues beyond the scope of this Article.

264. See Duke Energy Carolinas, Docket No. E-7, SUB 856, 2009 N.C. PUC LEXIS 701 (N.C. Util. Comm'n May 6, 2009).

265. See id. at 1. 
system." ${ }^{266}$ More broadly, Duke argued that the program would "promote the commercialization of solar facilities" in the state and "fill knowledge gaps so as to enable successful, widespread deployment of solar PV technologies." ${ }^{267}$ The Commission was unanimous in authorizing the project as "justified by the public convenience and necessity," finding that Duke was "entitled to an opportunity to fully recover its Program costs." ${ }^{" 68}$ The Commission made clear that in granting the certificate, Duke was not at risk of an "imprudence disallowance in a future case" resulting from its decision to proceed with the program. ${ }^{269}$ Still, any decisions Duke makes in the course of program implementation remain subject to question on the basis of "prudence or reasonableness."

North Carolina's RPS figured prominently in the Commission's analysis, but at present, of course, Florida does not have an RPS. Nevertheless, a similar, if less compelling, case for rate basing and cost recovery can still be made based on Florida's statutory provisions and policy statements encouraging renewable energy and solar energy in particular. ${ }^{271}$

\section{B. Siting Biomass}

Biomass generates most of Florida's still small renewable energy supply. ${ }^{272}$ While its technical potential is smaller than solar energy's, its market readiness is stronger than offshore wind's and ocean energy's, making biomass a promising near-term renewable resource for the state. ${ }^{273}$ Apart from renewable energy generally, the Legislature has shown support for biomass development most prominently by encouraging the Farm-to-Fuel Initiative within the Florida Department of Agriculture "to enhance the market for and promote the production

\section{Id.}

267. Id.

268. Id. at 2 .

269. Id. at 3 . In other words, the costs would not later be deemed imprudent expenditures and thus precluded from recovery by the utility.

270. Id. at 3.

271. See also Fla. ENERGy COMm'N, 2007 RePORT to THE Legislature 107 (2007) (noting that under the PSC's cost-of-service regulatory jurisprudence, "the general economic benefits of optimal DG location and active load controls accrue to all ratepayers, as do the costs for not optimally locating these resources" and suggesting that "[t]he PSC can, in coordination with the control area operators (i.e., utilities) and the FRCC [Florida Reliability Coordinating Council], establish target zones for DG deployment and active load management and target appropriate subsidies that result in lower costs for all Florida ratepayers and are economically neutral to utilities").

272. For a breakdown of biomass fuel consumption for electricity generation and combined heat and power plants in Florida, see SE. AGRIC. \& Forestry ENERGY Res. AlLIANCE, SOUTHERN BIOENERGY ROADMAP 33 (2009), available at http://www.saferalliance .net/projects/downloads/reports/RoadmapBook_webres.pdf.

273. See NAVIGANT, supra note 56, at 76 (discussing market maturity for biomass). 
and distribution of renewable energy from Florida-grown crops, agricultural wastes and residues, and other biomass and to enhance the value of agricultural products or expand agribusiness in the state."274

From the perspective of reducing greenhouse gas emissions, power plants that rely on renewable forest and crop-derived feedstocks are considered helpful because they can be, in theory, carbon neutral. According to the EPA, "although the burning of biomass also produces carbon dioxide, the primary greenhouse gas, it is considered to be part of the natural carbon cycle of the earth. The plants take up carbon dioxide from the air while they are growing and then return it to the air when they are burned, thereby causing no net increase."275 This claim, however, must be understood to be highly conditional. In the case of woody biomass, for example, it is understood that "[a]lthough carbon is released in the form of carbon dioxide when wood is burned, if the wood is harvested and burned at the rate it grows in the forest, no new carbon is added to the atmosphere. It is only if this condition of harvesting sustainably is met that the claim of carbon neutrality can be made."276

Rationale differs for treating other forms of alternative (not technically renewable) energy resources as biomass. ${ }^{277} \mathrm{~A}$ landfill gas

274. FLA. STAT. $\$ 570.954$ (2009).

275. See Clean Energy: Biomass, U.S. ENVTL. PROT. AGENCY, http://www.epa.gov/RDEE/energy-and-you/affect/non-hydro.html\#landfill (last visited Feb. 1, 2010); see also What are the Benefits of Biopower?, SO. AlLIANCE FOR CLEAN ENERGY, http://www.cleanenergy.org/index.php?/Learn-About-Detail.html?form_id=52\&item_id=28 (last visited Feb. 1, 2010) ("Burning biomass can be carbon neutral."). But see JOSHUA A. BLONZ ET AL., supra note 19, at 35-37 (assessing potential for GHG emissions reductions from biomass and biofuels, concluding that projections are too high considering broader range of factors); $T$. Searchinger et al., Use of U.S. Croplands for Biofuels Increases Greenhouse Gases Through Emissions from Land Use Change, 319 SCIENCE 1238, 1238-40 (2008); U.S. DEP'T OF ENERGY, RESPONSE: DOE ACTIVELY ENGAGED IN INVESTIGATING THE ROLE OF BIOFUELS IN GREENHOUSE GAS EMISSIONS FROM INDIRECT LAND USE CHANGE (May 28, 2008), available at http://www1.eere.energy.gov/biomass/news_detail.html?news_id=11794; RENEWABLE FUELS AGENCY, THE GALLAGHER REVIEW OF THE INDIRECT EFFECTS OF BIOFUELS PRODUCTION (2008), available at http://www.renewablefuelsagency.org/reportsandpublications/reviewofthein directeffectsofbiofuels.cfm (focusing on biofuels for transportation use).

276. See Frequently Asked Questions, BIOMAss ENERGY Res. CTR., http://www.biomasscenter.org/resources/faqs.html\#22 (last visited Nov. 1, 2009). The Biomass Energy Resource Center promotes the use of woody biomass for energy. See id.

277. It is certainly open to debate whether these non-renewable alternative energy sources should in fact be included in the definition of "biomass," thereby garnering the benefits of status as a "renewable energy" resource. Power Scorecard, an electricity supply scoring resource endorsed by prominent non-governmental organizations including Environmental Defense, Natural Resources Defense Council, and the Union of Concerned Scientists, "does not consider MSW [municipal solid waste] a renewable energy source, because the waste stream includes materials made from fossil resources; the sources of the plant material based content (e.g., paper and wood) are unpredictable; and the waste stream would be greatly reduced with environmentally preferable waste reduction and management practices." Electricity from Municipal Solid Waste, POWER SCORECARD, http://www.powerscorecard.org/ tech_detail.cfm?resource_id=10 (last visited Nov. 2009); see also ORG. FOR ECON. COOPERATION AND DEV. \& INT'L ENERGY AGENCY, BENIGN ENERGY? THE 
plant, for example, can capture methane gas released in waste decomposition and redirect it from the atmosphere to generate electricity. Burning municipal solid waste for energy is typically rationalized as a productive reuse that is preferable to disposal in a landfill. ${ }^{278} \mathrm{~A}$ common argument in support of all forms of biomass is that its use reduces reliance on fossil fuels for electricity. ${ }^{279}$

The siting context for biomass is complicated by this broad range of energy resources included in Florida's definition of biomass: forest and agricultural byproducts, but also animal waste, landfill gas, and trash. ${ }^{280}$ Regardless of their common statutory category, these resources are not equivalent in land use needs, community impacts, emissions, waste, and water use. We see some of these differences acknowledged in environmental permitting requirements and process, but only minimally in relation to siting.

\section{Regulatory Context}

As is the case with large-scale solar, the Siting Act provides the framework for siting typical biomass facilities above $75 \mathrm{MW}$. Likewise, smaller biomass facilities are subject to the standard land use approval process set out in the GMA or the revised expedited permitting statute. This dual regulatory context likely has greater implications for biomass projects than for solar energy, because a biomass plant is a typical industrial land use. The procedural and substantive aspects of the Siting Act - the streamlined permitting, Siting Board land use authority, and the DOAH context - solve more problems for a biomass plant. ${ }^{281}$ Compared with a PV solar array, which generates no waste, no emissions, and requires no water supply, a biomass facility will generally require a much

ENVIRONMENTAL IMPLICATIONS OF RENEWABLES 99 (1998), available at http://www.iea.org/publications/free_new_Desc.asp?PUBS_ID=1139 (observing that because landfill gas and solid waste are "by-products of modern civilization and a waste, they represent a non-sustainable source").

278. See, e.g., FLA. STAT. $\$ 377.709$ (2009) ("The Legislature further declares that the combustion of refuse by solid waste facilities to supplement the electricity supply not only represents an effective conservation effort but also represents an environmentally preferred alternative to conventional solid waste disposal in this state.").

279. This is not entirely true in the case of municipal solid waste. See Electricity From Municipal Solid Waste, U.S. ENVTL. PROT. AGENCY, http:/www.epa.gov/cleanenergy/energyand-you/affect/municipal-sw.html (last visited Nov. 1, 2009) ("Although MSW consists mainly of renewable resources such as food, paper, and wood products, it also includes nonrenewable materials derived from fossil fuels, such as tires and plastics.").

280. See Fla. STAT. § 366.91(2)(a) (2009).

281. See discussion supra Part II.B. The Florida DEP has provided some general permitting guidance for biomass facilities. See FlA. DEP'T OF ENVTL. PROT., RECOMMENDATIONS FOR Regulating Fat, OIL and Grease Processing and Biofuel Production Facilities in FLORIDA (2009) (addressing air, solid waste, wastewater, and other considerations for biofuel facilities "that produce either fuel additives, such as biodiesel or ethanol, or produce electricity from burning biomass"). 
longer list of environmental permits. ${ }^{282}$ The expedited permitting statute comes much closer to the Siting Act's predictability in terms of the length of time to receive approval and cost for an industrial use that may be opposed locally. ${ }^{283}$

The basic regulatory framework for siting biomass plants is supplemented by siting-related nuances for specific forms of biomass. At the organic end of the spectrum, forest and crop-derived biomass may be advantaged by a narrow modification of the GMA siting process for "rural agricultural industrial centers," which arguably can include biomass electrical plants. ${ }^{284}$ The term is defined as "a developed parcel of land in an unincorporated area on which there exists an operating agricultural industrial facility" that processes "any farm product ... or any biomass material that could be used, directly or indirectly, for the production of fuel, renewable energy, bioenergy, or alternative fuel as defined by law." 285 Eligible parcels are narrowed further by requirements that the existing facility employ at least 200 full-time employees and be located in an unincorporated area "within, or within 10 miles of, a rural area of critical economic concern." ${ }^{286} \mathrm{~A}$ landowner with a qualifying rural agricultural industrial center is authorized to apply for an amendment to the local comprehensive plan for the purpose of "expanding the existing center to include industrial uses or facilities that are not dependent upon but are compatible with agriculture and the existing uses and facilities."287 If the application meets certain criteria, ${ }^{288}$ the local government "shall"

282. See Angela Morrison Uhland, Improving Regulations for Biomass-Based Electrical Generating Facilities, 23 NAT. RES. \& ENV'T 15 (2008) (discussing uncertainty regarding environmental permitting requirements for biomass power plants and need for EPA to "issue guidance outlining all of the potentially applicable environmental standards for both construction and operation of biomass-based electrical generating facilities"); see also Angela Morrison Uhland et al., Presentation at the Farm to Fuel Summit: Environmental and Land Use Approvals for Biopower and Biofuel Facilities 7 (July 30, 2009), available at http://www.floridafarmtofuel.com/summit_2009.htm (listing zoning and land use approval, consumptive water use permit, wastewater discharge permit, environmental resource permit, federal wetland permit, federal stormwater permit, and air quality permit as needed for biomass plants).

283. The highly contentious failed siting of a biomass facility in Tallahassee is a recent example in which local opposition, motivated in large part by environmental justice concerns, ultimately caused the developer to abandon its proposal. See Biomass Gas and Electric (BG\&E) Tallahassee Renewable Energy Center, Permit Application Withdrawn, FLA. DEP'T OF ENVTL. PRot. (Feb. 2, 2009), http://www.dep.state.fl.us/air/emission/construction/tallahassee.htm (providing links to state documents connected with the $42 \mathrm{MW}$ facility proposed by BG\&E).

284. See 2009 Fla. Laws ch. 154.

285. FLA. STAT. $§ 163.3177(15)$ (b) (2009).

286. Id.; see also FLA. STAT. $\$ 288.0656(7)$ (2009) (defining "rural area of critical concern").

287. $§ 163.3177(15)(\mathrm{c})(2009)$.

288. See id. The plan amendment must not increase the site by more than 50 percent or 320 acres, whichever is greater; must create at least fifty new full-time jobs; must be supported with sufficient infrastructure for the expansion; and must "contain goals, objectives, and policies that will ensure that any adverse environmental impacts of the expanded center will be adequately 
transmit to the state any plan amendments needed to facilitate expansion of such centers as intended in the statute. ${ }^{289}$ In other words, the locality is required to amend its comprehensive plan to accommodate industrial uses compatible with agriculture at (what is probably a limited number of) qualifying sites.

At the other end of the spectrum, for municipal solid waste, the Legislature has encouraged siting so-called waste-to-energy (WTE) incinerators, "as an alternative" to constructing or expanding a landfill. ${ }^{290}$ This encouragement is made tangible in the form of mandated funding by electric utilities of local governmental solid waste facilities that generate electricity. ${ }^{291}$ WTE facilities are also favored with an exemption from the need determination for power plant expansions that would otherwise trigger the Siting Act (by bringing total capacity in excess of $75 \mathrm{MW}$ ). ${ }^{292}$ Municipal solid waste is the only form of biomass that receives these regulatory advantages. ${ }^{293}$ As a prerequisite to siting, however, a proposed WTE facility must satisfy criteria designed to address the inherent conflict between the state's interest in waste reduction and recycling and its reliance on waste as an energy source. ${ }^{294}$ For example, the applicant seeking approval to site and build a WTE facility must provide "reasonable assurance" that it is "a necessary part of the local government's integrated solid waste management program in the jurisdiction where the facility will be located and cannot be avoided through feasible and practical efforts to use recycling or waste reduction." ${ }^{295}$ An applicant must show it would be economically infeasible to make use of capacity at existing WTE facilities "within reasonable transportation distance" from the proposed site. ${ }^{296}$ The locality where the facility is sited must demonstrate that it maintains a solid waste

addressed and mitigation implemented or demonstrate that the local government comprehensive plan contains such provisions." Id.

289. See id.

290. See FLA. STAT. $\S 403.706$ (11) (2009). Each county in the state is obligated to meet the waste management and disposal needs "of all incorporated and unincorporated areas of the county." Id. § 403.706(1).

291. See Fla. STAT. $\$ 377.709$ (2009).

292. See id. $\$ 377.709(6)$ (allowing exemption from section 403.519 for solid waste facility expansions not greater than $50 \mathrm{MW}$, regardless of resulting total capacity of the facility).

293. Phosphate industry cogeneration plants, however, have a similar "expansion" exemption. See FLA. STAT. $\$ 403.506(1)$ (2009).

294. See FLA. STAT. \& 403.7061 (2009) (explaining that "[w]aste-to-energy facilities will continue to be an integral part of the state's solid waste management practices. However, the state is committed to achieving its recycling and waste reduction goals and must ensure that waste-to-energy facilities are fully integrated with the state's waste management goals. Therefore, the Legislature finds that the department should evaluate applications for waste-toenergy facilities ... to confirm that the facilities are part of an integrated waste management plan.").

295. Id. $\S 403.7061(3)(\mathrm{a})$.

296. Id. § 403.7061(3)(b). 
management and recycling program meeting certain requirements, ${ }^{297}$ and the facility must be in state and local land use compliance under the GMA..$^{298}$

\section{Other Siting Considerations}

Community impact and land use compatibility are paramount siting considerations for biomass. Biomass power plants are industrial land uses that generate air emissions, wastewater, ash, and other wastes. ${ }^{299}$ Depending on the site selected, biomass plants can raise environmental justice concerns and general local opposition, similar to other polluting industrial land uses. ${ }^{300}$ Even assuming carbon neutrality, local air quality will still be degraded as carbon dioxide that would have been released slowly over time, over many square miles, is instead released from a single local site. For this reason, despite supporting biomass as an energy resource, the Union of Concerned Scientists insists on protection of public health as a core principle for biomass development, explaining that "some bioenergy applications can degrade air, water, or land quality, creating tradeoffs between the potential benefits and public health risks." ${ }^{301}$ Florida law affirms that "[t]he generation, transmission, and delivery of electricity should be accomplished with the least detriment to the environment and public health." ${ }^{302}$ Environmental and public health

297. Id. $\$ 403.7061(3)(\mathrm{c})-(\mathrm{g})$.

298. Id. $\S 403.7061(3)(\mathrm{h})$.

299. The results of chemical analysis of ash from waste-to-energy facilities located in Florida are documented to include antimony, arsenic, beryllium, cadmium, chromium, copper, lead, mercury, nickel, selenium, silver, thallium, and zinc. See Waste to Energy Ash Evaluation Results, FLA. DEP'T OF ENVTL. PROT. (Mar. 24, 2009), http://p2000.dep.state.fl. us/waste/ash/wte_about.htm (searchable by facility and pollutant); see also FLA. DEP'T OF ENVTL. PROT., RECOMMENDATIONS FOR REgulating FAT, OIL AND GREASE PROCESSING AND BIOFUEL PRODUCTION FACILITIES IN FLORIDA 6 (2009) ("[F]acilities burning biomass as fuel will be regulated in the same manner as other incinerators.").

300. Local opposition to a polluting facility is often derided as stemming from a selfinterested "not-in-my-backyard," or NIMBY, mentality. That reductive view discounts the earnest public interest environmental concerns that drive many local organizers to oppose a siting decision. Likewise, environmental justice advocates, even when focused on a particular site, are working toward larger distributive equity goals. See generally Luke W. Cole, Environmental Justice Litigation: Another Stone in David's Sling, 21 FORDHAM URB. L.J. 523 (1994) (assessing efficacy of context-specific legal strategies for broader environmental justice goals.) This is not to say that mere NIMBYism is not part of the equation, but the term NIMBY fails to capture the more nuanced and legitimate concerns that local opposition brings to the public debate.

301. UNION OF CONCERNED SCIENTISTS, PRINCIPLES FOR BIOENERGY DEVELOPMENT 3 (2007), available at http://www.ucsusa.org/clean_energy/technology_and_impacts/energy_ technologies/smartbioenergy.html.

302. FLA. STAT. $\$ 337.901(7)(\mathrm{c})(2009)$. 
concerns are likely to be highest in connection with siting WTE biomass facilities. $^{303}$

Land use efficiency is an even more critical consideration for biomass than for PV arrays. Of all renewable resources, "biofuels and biomass burning of energy crops for electricity take the most space per unit of power."304 Directing biomass plants to brownfields or other previously developed sites where feasible can minimize land-based environmental impacts. ${ }^{305}$ The EPA lists nineteen candidate landfills in Florida for landfill gas-to-energy projects, ${ }^{306}$ for example, and the NREL "limbo lands" study identified twenty-five Florida brownfields as highpotential sites for biopower plants. ${ }^{307}$ While these or similar sites may satisfy key logistical criteria, the air emissions, noise, waste, and truck traffic associated with a biomass facility, unlike PV, bring community impact to the fore. Will siting a biomass facility on a brownfield site exacerbate or prolong environmental injustices in the community? Florida's brownfields statute incorporates environmental justice into its public participation provisions, defining the term to mean "the fair treatment of all people of all races, cultures, and incomes with respect to the development, implementation, and enforcement of environmental

303. The municipal solid waste incinerated at WTE facilities may include, by definition, "sludge unregulated under the federal Clean Water Act or Clean Air Act, sludge from a waste treatment works, water supply treatment plant, or air pollution control facility, or garbage, rubbish, refuse, special waste, or other discarded material, including solid, liquid, semisolid, or contained gaseous material resulting from domestic, industrial, commercial, mining, agricultural, or governmental operations." FLA. STAT. \$ 403.703(32) (2009) (defining "solid waste"). Burning municipal solid waste "produces nitrogen oxides and sulfur dioxide as well as trace amounts of toxic pollutants, such as mercury compounds and dioxins." Electricity from Municipal Solid Waste: Air Emissions Impacts, U.S. ENVTL. PROT. AGENCY, http://www.epa.gov/cleanenergy/ energy-and-you/affect/municipal-sw.html (last visited Nov. 1, 2009).

${ }^{304}$ Robert McDonald, et al., Energy Sprawl or Energy Efficiency: Climate Policy Impacts on Natural Habitat for the United States of America, PLos ONE 4(8): 6802 (2009).

305. Another efficient siting approach, where feasible, is co-firing in existing coal plants, allowing biomass power plants to take advantage of existing infrastructure. This does not result in new electrical generation, but displaces a percentage of the plant's coal-derived power. BLONZ ET. AL., supra note 19 , at 33.

306. See Landfill Methane Outreach Program: Landfill Gas Energy Projects and Candidate Landfills, U.S. ENVTL. PROT. AGENCY (Oct. 1, 2010), http://www.epa.gov/lmop/projectscandidates/index.html. The map identifies nineteen candidate sites and sixteen operational projects in Florida.

307. NAT'L RENEWABle ENERgy LABORATORY, CONVERTING LiMBO LANDS TO ENERGY-GENERATING STATIONS: RENEWABLE ENERGy TECHNOLOGIES ON UNDERUSED, FORMERLY CONTAMINATED SITES 28-29 (2007). All sites met the criteria of being located within fifty miles of major roads, ten miles of major transmission lines, fifty acres or larger in size, and located in a county with requisite total biomass residues. See also EPA Tracked Sites in Florida with Biopower Facility Siting Potential, ENVTL. PROT. AGENCY (Aug. 24, 2009), http://www.epa.gov/renewableenergyland/maps.htm. It is not clear whether there is overlap between EPA's landfill and brownfields lists. 
laws, regulations, and policies. ${ }^{308}$ Is the site sufficiently insulated from residences and schools to make reuse of the site ideal? Early public involvement in the site selection process will help bring pertinent concerns to light early enough to expand the range of alternative sites for review. ${ }^{309}$

Two additional opportunities exist for land use efficiency in siting biomass, neither of which is likely to raise new community impact concerns. The first, where feasible, is not to site a new facility at all but to convert or co-fire an existing coal-fired power plant with biomass to displace energy from coal. A full conversion, and co-firing to a lesser degree, reduces community impacts of an existing facility. ${ }^{310}$ The second is to use biomass for onsite combined heat and power production, a form of DG that makes use of already developed land. ${ }^{311}$

A third siting consideration for biomass is geographic constraints, which may limit the range of viable sites. Power plants using forest and crop-derived biomass need ready access to feedstocks, transmission lines, and water supply. ${ }^{312}$ Biomass plants "require large areas of land for

308. FLA. STAT. § 376.79(9) (2009). The Brownfields Rehabilitation Act defines the term and requires that, for each rehabilitation of a brownfield, an "advisory committee" must be formed "for the purpose of improving public participation and receiving public comments on rehabilitation and redevelopment of the brownfield area, future land use, local employment opportunities, community safety, and environmental justice." FLA. STAT. § 376.80(4). Environmental justice is not raised as an issue of concern in the Power Plant Siting Act, nor in the DEP's Power Plant Application Guide. See FLA. STAT. §§ 403.501-.518 (2009); FLA. DeP’T OF ENVTL. PROT., POWER Plant APPLICATION GuIDE, available at http://www.dep.state.fl.us/siting/files/renew_resource_permitting.pdf (last visited Oct. 10, 2010) (requesting that applicants address a list of potential socio-economic factors, not including racial composition of affected population). It is also not raised in the Growth Management Act, FLA. STAT. \$\$ 163.3164-.3217 (2009), so local comprehensive plans can but are not specifically encouraged or required to consider environmental justice in planning.

309. For the importance of public participation in environmental justice disputes, see Sheila Foster, Public Participation, in THE LAW OF ENVIRONMENTAL JUSTICE: THEORIES AND PROCEDURES TO ADDRESS DISPROPORTIONATE RISKS (Michael B. Gerrard \& Sheila R. Foster eds., 2d ed. 2008).

310. See U.S. Envtl. Prot. agency \& Nat'l Renewable Energy laboratory, STATE BIOENERGY PRIMER 30 (2009) ("Biopower facilities using biomass feedstocks in certain types of direct combustion technologies (e.g., fluidized bed boilers) and gasification technologies (e.g., integrated gasification combined cycle, or IGCC) have reduced $\mathrm{SO}_{2}$ and $\mathrm{NO}_{x}$ emissions, compared to coal-only electricity production.") (internal citations omitted).

311. See Se. AGRic. \& Forestry ENERgy Res. AllianCE, supra note 272, at 31. For general information on biomass CHP systems, see Combined Heat and Power Partnership: Biomass CHP, U.S. ENVTL. PROT. AGENCY, http://www.epa.gov/chp/basic/renewable.html (last visited Nov. 1, 2009); for information on assessing a site's potential for successful CHP, see Combined Heat and Power Partnership: Streamlining Project Develpment, U.S. ENVTL. PROT. AGENCY, http://www.epa.gov/chp/project-development/index.html (last visited Nov. 1, 2009).

312. Siting should take into account, for example, the effect of proximity to a water resource caution area, "a geographic area, officially designated by the Governing Board [of a water management district] by rule that is experiencing, or is anticipated to experience within the next 20 years, critical water resource problems as provided by the criteria identified in subsection 40A-2.801(1), F.A.C." FLA. ADMIN. CODE ANN. r. 40A-2.021(58) (2009); see also FLA. ADMIN. 
equipment and fuel storage." ${ }^{313}$ Landfill gas plants must, by definition, be sited at existing landfills, and not every landfill has the same recovery potential. ${ }^{314}$ WTE facilities are bound by the siting constraints in section 403.7061 of Florida Statutes, discussed above, which sets out jurisdictional need and waste management policy-based siting criteria that have nothing to do with the land characteristics of any particular site.

For traditional biomass, a more generalized but still geographic constraint may emerge over time: competition in the use of agricultural land within the state. A long-term concern is the potential for biofuels, biorefineries, and power plants to compete for the same wood or crop feedstocks. ${ }^{315}$ In the case of wood, "existing paper, pulp, fiber, and wood products industries are concerned that bioenergy may increase the price of their feedstocks." 316 It is possible that "too much demand for wood concentrated in one geographic area may result in depletion of the biomass resource." ${ }^{317}$ Even if the transportation and electricity sectors ultimately compete "for the same biomass products, both sectors place demands on limited agricultural land resources" as well as "put stress on other sectors that require agricultural products, such as livestock and other grain markets." 318

Finally, and most importantly, a fourth siting consideration with local and global implications is land use sustainability in the cultivation and harvest of forest or crop-derived biomass. Although there is general consensus that plant-based biomass has potential as a sustainable source of electricity and fuel, "a rapid global expansion of bioenergy development could have unwanted environmental and economic consequences, possibly including reduced global capacity to produce

CODE ANN. r. 40A-2.802 (2009) (specifically addressing permitting in water resource caution areas).

313. Electricity from Non-Hydroelectric Renewable Energy: Biomass Land Resource Use, U.S. ENVTL. PROT. AGENCY, http://www.epa.gov/cleanenergy/energy-and-you/affect/nonhydro.html\#biomass (last visited Nov. 1, 2009).

314. Energy Projects and Candidate Landfills, U.S. ENVTL. PROT. AGENCY, http://www.epa.gov/lmop/projects-candidates/index.html (last visited Nov. 3, 2010) (providing information on selection of candidate sites); see also U.S. ENVTL. PROT. AGENCY, FLORIDA STATE Primer: A PRIMER ON DEVEloping Florida's LANDFILl-Gas-TO-ENERGY POTENTIAL (2000), available at http://nepis.epa.gov/Exe/ZyPURL.cgi?Dockey=900O0500.txt.

315. See Biopower Overview, SOUTHERN ALLIANCE FOR ClEAN ENERGY, http://www.cleanenergy.org/index.php?/Learn-About-Detail.html?form_id=52\&item_id=28 (last visited Nov. 1, 2010). Although this is not currently a pressing concern in Florida, the Navigant study found potential for biomass power to compete for resources with biofuels applications. See NAVIGANT, supra note 57, at 221.

316. Biopower Overview, SOUTHERN ALLIANCE FOR ClEAN ENERGY, http://www.cleanenergy.org/index.php?/Learn-About-Detail.html?form_id=52\&item_id=28 (last visited Nov. 1, 2010).

317. Id.

318. BLONZ ET AL., supra note 19, at 2. 
food, fiber, and industrial materials." ${ }^{319}$ A key concern for cultivated biomass is that converting agricultural lands from food to fuel production will result in destruction of other ecologically valuable land elsewhere to make room for the displaced food crops. ${ }^{320}$ Without assurance of sustainable practices, these risks are the source of serious concern and cast doubt on the biomass "carbon neutrality" claim. There are numerous organizations working to develop guidance for sustainable biomass development, but to date there are no enforceable sustainability standards for biomass in Florida or at the federal level ${ }^{321}$ Florida has best management practices for silviculture, ${ }^{322}$ which property owners can adopt voluntarily, but there is no specific guidance for biomass

319. UNION OF CONCERNED SCIENTISTS, PRINCIPLES FOR BIOENERGY DEVELOPMENT 2 (2007), available at http://www.ucsusa.org/clean_energy/technology_and_impacts/energy _technologies/smartbioenergy.html; see also U.S. ENVTL. PROT. AGENCY \& NAT'L RENEWABLE ENergy Laboratory, STATE Bioenergy PRimer 26 (2009) ("Potentially adverse environmental impacts could result if increased production is not handled sustainably, including air and water pollution, negative impacts of direct and indirect land use changes, and increased water consumption."); BLONZ ET AL., supra note 19, at 35-38 (discussing environmental impacts of biomass/biofuel production); Erik Bluemel, Biomass Energy: Ensuring Sustainability Through Conditioned Economic Incentives, 19 GEO. INT'L ENVTL. L. REV. 673 (2007) (discussing environmental impacts of biomass cultivation for biofuels and combustion, with an international scope); FRIENDS OF THE EARTH \& INST. FOR AGRIC. AND TRADE POL'Y, http://www.sustainablebiomass.org (last visited Feb. 2010) (asserting that "biomass production done wrong . . . could actually decrease biodiversity, soil health, water quality and wildlife habitat, with minimal or negative greenhouse gas reduction benefits").

320. Indirect land use changes are more directly linked to biofuel crops than biomass for electricity, but both are implicated to the extent that biomass for power production is derived from biofuel crop residues. See Bluemel, supra note 319; see also UNION OF CONCERNED SCIENTISTS, LAND USE ChANGes AND BIOFuels-FaCt SHEeT (2008), available at http://www.ucsusa.org/clean_vehicles/technologies_and_fuels/biofuels/Land-Use-Changes-andBiofuels.html.

321. See e.g., COUNCIL ON SuSTAINABle BiOMASS PROD., http://www.csbp.org (last visited Feb. 1, 2010) (developing a Sustainability Standard for Biomass Production); FRIENDS OF THE EARTH \& INST. FOR AGRIC. AND TRADE POL'Y, http://www.sustainablebiomass.org (last visited Feb. 1, 2010) (developing principles to "serve as a basis for policy development, criteria for local development and commercialization of biomass projects, and as a framework for drafting more specific technical international standards and codes of practice for sustainable biomass production and use"). The Department of Energy Biomass Program is also engaged in into the biomass sustainability research. See DEP'T OF ENERGY BIOMASS PROG., http://www1.eere.energy.gov/biomass (last visited Jan. 2010). At least one state, New York, has considered requiring that sustainable practices be used for biomass-based projects for eligibility under its renewable portfolio standard. See Uhland, supra note 282 (citing N.Y. STATE ENERGY Research and Dev. AUTh., New York State Renewable Portfolio Standard: BIOMASS GUIDEBOOK (2006)). It is not clear that this was ever formally adopted as policy.

322. See Fla. Dep'T of Agric. \& Consumer Serv., Florida Silviculture Best MANAGEMENT PRACTICES (2003), available at http://www.fldof.com/forest_management/ bmp/index.html; see also Best Management Practices for Silviculture and Notice of Intent to Implement, FLA. DEP'T OF AGRIC. \& CONSUMER SERV., http://www.doacs.state.fl.us/ onestop/forms/11305.pdf (last visited Oct. 10, 2010) (providing information and form for landowner voluntary notice of intent to implement best management practices). 
development. ${ }^{323}$ As facilities are sited in the absence of such standards, careful site selection to avoid unwanted consequences is especially important. Sustainability considerations for a proposed site might include: How far is the facility from its feedstock? If biomass is carried in by truck from a distant source location, how much tailpipe emissions will the hauling trucks produce? Is the site supporting a conversion of land from food production to biofuel production, and are there alternative sites that would avoid this conversion? When biomass power plants rely on biofuel or other crop residues, whether and how much can be sustainably removed is a site-by-site determination, as "these resources also have an important role in maintaining soil fertility and protecting cropland against erosion." 324 Such questions underscore the need to measure perceived benefits of biomass energy projects against their full range of impacts, including processing and ongoing operations. ${ }^{325}$

\section{OPPORTUNITIES TO GUIDE RENEWABLE ENERGY SITING}

With Florida's renewable energy development still in its early stages, a window of opportunity exists for the state and for local governments to actively guide siting. There are convincing reasons to craft siting policy now, at the state and local level, instead of responding project by project, and controversy by controversy.

First, early planning can help avoid misguided and wasteful land use. Planning for renewable energy's acreage demand will allow for a deliberate integration of conservation and wildlife protection objectives and renewable energy goals. Renewable energy projects can divide environmental advocates in ways that a fossil fuel plant does not. The sad irony is that this divisiveness can be self-defeating. With this dynamic at play, one commentator observed, it's "[n]o wonder environmentalists are

323. Other state forest practice laws cover woody biomass removals insomuch as they are a type of forest management. See ALEXANDER M. EVANS \& RoBERT T. PERSHEL, Forest GUILD, AN ASSESSMENT OF BIOMASS HARVESTING GuIDELINES 5 (2009) (reviewing biomass harvesting guidelines or standards that cover biomass removals from Maine, Minnesota, Missouri, Pennsylvania, Wisconsin, parts of Canada, and the Forest Stewardship Council). Florida's Division of Forestry was directed to assess forest-derived biomass, and a Final Woody Biomass Economic Study was delivered to the Governor and the Legislature by Mar. 1, 2010, available at http://www.fldof.com/forest_management/fm_pdfs/Final\%20Report\%20Woody\% 20Biomass \%20Economic\%20Study.pdf.

324. SE. AGRIC. AND FORESTRY ENERGY RES. ALLIANCE, supra note 272, at 43.

325. See Principles, Friends of THE EARTH \& INST. FOR AgriC. AND TRADE POL'Y, http://www.sustainablebiomass.org/principles.html (last visited Oct. 10, 2010) ("The full life cycle of biomass production (including processing for energy) must significantly reduce greenhouse gas emissions. As part of achieving this objective, the use of fossil fuels in the production and processing of biomass crops should be minimized, prevented whenever possible, and eventually phased out. Selection, production, and use of biomass crops should also result in reduced greenhouse gas emissions."). 
more effective opposing renewables than fossil fuel power projects." ${ }^{326}$ Of course, there is no inherent conflict in supporting renewable energy and opposing a particular site for development. Bringing the myriad environmental objectives together early may allow advocates and policymakers to avoid or reconcile potential conflicts between otherwise compatible aims. ${ }^{327}$

Second, guiding renewable energy siting can reduce community strife. The "smaller-capacity, more dispersed nature of renewable energy technologies necessitates a larger number of siting decisions, increasing the chances and likelihood of public opposition." 328 Local governments and community organizations can determine what kinds of energy projects are desirable, how to attract them, and where to site them, which is a task more easily done without a proposal on the table. Once a controversial project is under review, a win-or-lose dichotomy inevitably frames deliberations and the public exchange. Disagreements will be more divisive and emotions will run high. In the context of generalized public approval of renewable energy, it should be possible to bypass some of the stereotypical siting fiascos that can turn friends against each other and waste time, money, and effort, usually on all sides. In this sense, planning ahead also helps developers of renewable energy projects. Smart developers will be looking for ways to steer clear of siting difficulties and focus on sites in communities that want their projects. ${ }^{329}$ Planning can also avoid the risk that, "in the context of a dispute, the viewpoint of the party with more money to mount court battles or greater local political influence may prevail over sound policy." 330 Building local consensus in advance may be the most effective form of "streamlining" for renewable energy.

Third, although there are numerous ways the state can assist with siting issues, local governments have a great deal of power in this arena. Often "action by local government can be determinative of whether a

326. Robert D. Kahn, Siting Struggles: The Unique Challenge of Permitting Renewable Energy Power Plants, Elec. J., Mar. 2000, at 29 (discussing the local context for siting a renewable energy facility from the perspective of project proponent).

327. See, e.g., Defenders OF Wildlife ET AL., KEY PRINCIPLEs: Balancing RENEWABLE ENERGY DEVELOPMENT AND LAND CONSERVATION IN A WARMING WORLD (2009), available at http://www.defendersofwildlife.org/resources/publications/policy_and_ legislation/balancing_renewable_energy_development_and_land_conservation_in_a_warming_w orld.pdf (representing effort of environmental non-governmental organizations to reach consensus on principles for avoiding such conflicts).

328. DORIS ET AL., supra note 5, at 133.

329. See Colloquy, EBA Climate Change Primer: Financing a Renewable Project, 29 ENERGY L. J. 195, 208 (2008); Kahn, supra note 326, at 29 ("Successful renewable developers exceed what regulators and the community expect. They wisely take their projects beyond compliance.").

330. Edna Sussman, Reshaping Municipal and County Laws to Foster Green Building, Energy Efficiency, and Renewable Energy, 16 N.Y.U. ENVTL. L.J. 1, 23 (2008). 
renewable energy resource is actually developed, since the local government generally controls the siting of the facilities." 331 New state siting policies do not have to be in place for localities to take the lead in guiding renewable energy projects to the most appropriate sites. Indeed, it may be to their advantage to initiate local planning without waiting for state policies that may mandate how localities treat project proposals.

For all these reasons, now is the ideal time to make the most of opportunities to guide renewable energy siting. Key opportunities include the following:

Facilitate siting for widespread distributed generation. The land use efficiency and conservation benefits of DG are unsurpassed, and the potential energy supply from rooftop PV warrants making its expansion a top priority, comparable to efforts to modernize the grid. As state and local governments anticipate and respond to effects of climate change, decentralized power will also take on greater importance for climate adaptation. ${ }^{332}$ Coastal energy infrastructure is vulnerable to sea-level rise and the increase in severe weather expected to result from climate change. Florida and the other Gulf states are likely to suffer the greatest impacts from these phenomena. ${ }^{333}$ Whether with rooftop solar panels or other onsite energy generators, expanding DG would have the effect of spreading "climate-related risk over a large geographic area, thereby reducing the impact of climate related events (e.g., a hurricane) focused in a specific area." 334

The state has already eliminated a number of regulatory barriers to DG siting, but interconnection for rooftop systems can be improved to conform with best practices, allowing for higher energy generation and creating standard procedures for all utilities. ${ }^{335}$ In the interest of maximizing DG within grid constraints, the state is in a position to facilitate geographically strategic DG installation in response to "congestion costs on specific locations on the transmission and distribution system." 336 The Florida Energy Commission (FEC)

331. Id. at 23; see also Patricia E. Salkin, Sustainability and Land Use Planning: Greening State and Local Land Use Plans and Regulations to Address Climate Change Challenges and Preserve Resources for Future Generations, 34 WM. \& MARY ENVTL. L. \& POL'Y REV. 1 (2009).

332. See Res. For the Future, AdAPTing to Climate Change: The Public Policy RESPONSE-PUBLIC INFRASTRUCTURE 30-31 (2009). Climate adaptation is the "adjustment in natural or human systems in response to actual or expected climatic stimuli or their effects, which moderates harm or exploits beneficial opportunities." Climate Change - Health \& Environmental Effects: Adaptation, U.S. ENVTL. PROT. AGENCY, http://www.epa.gov/ climatechange/effects/adaptation.html\#ref (last visited Feb. 1, 2010).

333. See U.S. Global Change Research Program, supra note 28, at 59.

334. Res. for the future, adapting to Climate Change: The Public Policy RESPONSE-PUBLIC INFRASTRUCTURE 30-31 (2009).

335. See generally NETWORK FOR NEW ENERGY CHOICES ET AL., supra note 207.

336. FLA. ENERGY COMM'N, 2007 REPORT TO THE LEGISLATURE 107 (2007) (Recommendation 67: Distributed Energy), available at http://myfloridaclimate.com/climate 
recommended in 2007 that the PSC coordinate with utilities and the Florida Reliability Coordinating Council to "establish target zones for DG deployment and active load management. ${ }^{\prime 337}$ This could be made even more effective combined with financial or other incentives to support PV and other DG modes in high-need areas of the state. The state could explore a utility ownership model to facilitate a coherent deployment of PV in congested areas as the FEC proposed. To guide siting indirectly, the state could require that "local governments, working in conjunction with their local electric and natural gas utilities, make provisions for siting small generation facilities close to demand centers." ${ }^{338}$ According to the FEC, this would reduce energy lost in transmission and minimize the need for substations and transmission lines. ${ }^{339}$

At the local level, now is the time to review existing solar access and related ordinances, if they exist, and conform them to best practices as closely as possible. ${ }^{340}$ With local permitting so consistently cited as a barrier, local governments should reevaluate and simplify their processes, if necessary. As part of this evaluation, local governments might revisit their comprehensive plans and propose amendments to support rooftop solar in appropriate elements. For example, under the GMA it is mandatory that all comprehensive plans include housing elements. ${ }^{341}$ This would be an ideal place to add or strengthen the goals and policies for promoting and supporting customer-sited DG. ${ }^{342}$ Finally, site guidance for new construction that accommodates renewable energy devices can assist with local DG siting in the future. ${ }^{343}$

Guide projects to sites that maximize land use efficiency and minimize environmental and community impacts. A project that can fit into a

_quick_links/florida_energy_climate_commission/energy_climate_change_policy/florida_energy _commission_2006_2007 (last visited Nov. 2009).

337. Id.

338. Id. at 106 (2007) (Recommendation 66: Provide for Future Siting for Distributed Generation Systems), available at http://myfloridaclimate.com/climate_quick_links/llorida _energy_climate_commission/energy_climate_change_policy/florida_energy_commission_2006_ 2007. The FEC was in existence in 2006 and 2007, and has since been dismantled and functionally replaced with the Florida Energy and Climate Commission.

339. Id.

340. See, e.g., PITT, supra note 227 , at $47-52,87$.

341. See FLA. STAT. \$ 163.3177(6)(f) (2009).

342. See id. $\S 163.3177(6)(f)(i)$ (requiring policies on the "use of renewable energy resources").

343. The NREL State of the States 2009 report highlights the EPA State Best Practices website and the International Council for Local Environmental Initiatives' online information as good resources that can help state and local governments assist decision makers in weighing options and taking steps toward renewable energy development. DORIS ET AL., supra note 5, at 132. Another valuable resource is DSIRE, supra note 5 , which compiles information on state and federal policies. See also Sussman, supra note 330, at 34-35 (discussing opportunities for localities to plan for integration of solar panels into new construction). 
preexisting industrial site is less likely to harm the landscape or impose new burdens on neighbors. ${ }^{344}$ The state could support renewable energy developers and communities alike by supplementing the EPA/NREL analyses of potentially suitable brownfield and landfill sites in Florida with more local information and context. ${ }^{345}$ Incentives for renewable energy projects should be tied to defined siting priorities, favoring reuse of contaminated sites or other developed land and disfavoring greenfield sites.

At the local level, facility siting can be guided by amendments to the future land use element, and related changes to LDRs, so that they identify desirable sites within the community for particular energy projects. This would be one way to comply with the 2008 amendment to Chapter 163 requiring that future land use elements address "energyefficient land use patterns accounting for existing and future electric power generation and transmission systems." ${ }^{346}$ Textual guidance and map designations of this kind could be useful in steering projects of all sizes to the right sites. Even in the context of the Siting Act, it could be helpful for a community in the land use consistency determination process to have clearly spelled out the public preferences on the land use map.

Another planning tool is a renewable energy element in the local comprehensive plan. ${ }^{347}$ An energy element is not mandatory under Chapter 163, and although the state could make it so, ${ }^{348}$ there is no reason for local governments to wait for direction. ${ }^{349}$ Developing an energy element is an opportunity for elected officials, planners, local interest

344. See Kahn, supra note 326 , at 23 (discussing the local context for siting a renewable energy facility from the perspective of a project proponent).

345. EPA has developed a database that includes GIS-based maps, an interactive map, and associated data spreadsheets, that show the expected suitability of contaminated sites for renewable energy production. See Siting Renewable Energy on Potentially Contaminated Land and Mine Sites, U.S. ENVTL. PROT. AGENCY, http://www.epa.gov/renewableenergyland (last visited Oct. 10, 2010).

346. $\S 163.3177(6)(a)$, amended by H.B. 697, 111th Leg. (Fla. 2009) (enacted).

347. This opportunity was also highlighted by the FEC. See FLA. ENERGY COMM'N, 2007 REPORT TO THE LEGISLATURE 101 (2007) (Recommendation 61: Energy Element in Comprehensive Plans), available at http://myfloridaclimate.com/climate_quick_links/ florida_energy_climate_commission/energy_climate_change_policy/florida_energy_commission_ 2006_2007. For an overview of local efforts to address energy and related issues in using comprehensive plans, see Salkin, supra note 331.

348. Apparently, "there have been several unsuccessful attempts to include a 'utility element' as a required component in comprehensive plans." FLA. ENERGY COMM'N, 2007 REPORT TO THE LEGISLATURE 101 (2007) (Recommendation 61: Energy Element in Comprehensive Plans), available at http://myfloridaclimate.com/climate_quick_links/florida_ energy_climate_commission/energy_climate_change_policy/florida_energy_commission_2006_2 007.

349. See $\$ 163.3177(7)(k)$ (making optional "other elements particular to, and necessary for, the area concerned"). 
groups, and the public to agree on what kind of projects they want to attract to the area and to identify acceptable sites for renewable energy facilities. For this purpose, local governments do not have to employ the state's definition of "renewable energy"; they can encourage particular resources that are locally preferred. Likewise, localities should ensure that renewable energy sources, categorically or specifically, are included "as uses in the appropriate land use category of the future land use element and identify locations for such uses on the future land use map." 350

Develop sustainability standards for biomass development. The state should develop sustainability standards for all forms of biomass development to clarify how to select appropriate facility sites and ensure sustainable operations. Beyond the environmental benefits of ensuring biomass sustainability, trusted standards could ease much of the local opposition to biomass facilities in their communities. As the multistakeholder Council for Sustainable Biomass Production has emphasized, standards can benefit biomass developers by increasing access to new markets while attracting and maintaining local demand for biomass. ${ }^{351}$ Even without state standards, local governments can develop sustainability plans for forest- or crop-based biomass plants, or at a minimum press developers for commitments to explicit practices that will protect the local environment and ensure responsible harvesting. ${ }^{352}$

Focus expedited permitting on siting well, not just siting quickly. With its revisions to the expedited permitting statute, the Legislature missed an opportunity to link faster approvals to better siting. Like the Siting Act, it is energy developer-driven, and governmental action is fundamentally reactive. The revised law also fails to account for the fact that two "renewable energy" projects could have vastly different pollution profiles. As this article has emphasized, the context for siting renewable energy facilities is not identical for every resource included in Florida's definition of "renewable energy." Expedited permitting and siting may be desirable for a small solar PV array, but perhaps not for a waste-toenergy facility. Compatibility between a new power plant and its surroundings, natural or developed, is an important goal that is not likely

350. Terrell K. Arline, Renewable Energy: A Local Government Perspective 12.3 (2009) (unpublished CLE material) (on file with author). The future land use plan is based on surveys, studies, and data regarding the area, including energy-efficient land use patterns accounting for existing and future electric power generation and transmission systems. See FLA. STAT. § 163.3177(6)(a) (2009).

351. See COUNCIL ON SUSTAINABle Biomass PROD., Why A SUSTAINABILITY STANDARD WILL BE OF VALUE TO BIOMASS PRODUCERS (2009), available at http://www.csbp.org.

352. See, e.g., GAINESVILlE REG'L UTIL., STEWARDSHIP INCENTIVE PLAN FOR BIOMASS FUEL PROCUREMENT (2009), available at http://www.gru.com/Pdf/futurePower/ADOPTED $\% 20$ April \%202\%202009\%20Forest-Produced\%20Biomass\%20Fuel\%20Plan.pdf. 
to be well served by reduced public participation and truncated opportunities to challenge poor decisions.

There is potential, however, in the "regional permit action teams" that the statute employs to coordinate state agencies and opt-in local government reviews. If empowered to do so, these teams could take affirmative steps in advance of eligible applications to assist local governments in just the kind of planning work that is needed to guide facilities to the best sites.

Plan for siting emerging energy resources offshore. Florida has no regulatory framework for offshore wind and ocean energy. This is not really surprising, given that no projects are on the immediate horizon; however, recent federal developments designed to facilitate offshore energy projects should spur Florida to begin actively preparing to address the range of issues an offshore proposal of either kind would present. Under the Energy Policy Act of 2005, the Minerals Management Service (MMS) within the U.S. Department of the Interior has authority over renewable energy projects on the Outer Continental Shelf. ${ }^{353}$ In April 2009 , the MMS promulgated a final rule providing a long-awaited regulatory framework for leasing federal submerged lands in ocean waters for offshore renewable projects. ${ }^{354}$ This important step is likely to lead to an increased number of offshore proposals in the United States. ${ }^{355}$

A key difference between siting onshore and offshore energy facilities is jurisdictional; state control over activities beyond state waters is limited. Even without jurisdiction over federal waters, however, Florida has important opportunities to influence energy project siting off its coasts. Capitalizing on these opportunities will take preparation, in advance of an actual project proposal. Most importantly, Florida can exert influence through the Coastal Zone Management Act (CZMA), which requires federally permitted offshore activities be consistent "to the maximum extent possible" with "enforceable policies" of the state's

353. This authority was granted to MMS in the Energy Policy Act of 2005, amending the Outer Continental Shelf Lands Act. See 43 U.S.C. $\$ 1337(p)(1)$ (2006). Through a Memorandum of Agreement between the MMS and FERC, FERC will retain jurisdiction over hydrokinetic projects offshore. See Memorandum of Understanding between Department of the Interior and Federal Energy Regulatory Commission (Apr. 9, 2009), available at http://www.ferc.gov/legal/maj-ord-reg/mou/mou-doi.pdf. The MMS has been reorganized and is now the Bureau of Ocean Energy Management, Regulation, and Enforcement, http://www.boemre.gov (last visited Nov. 9, 2010).

354. See Renewable Energy and Alternative Uses of Existing Facilities on the Outer Continental Shelf, 74 Fed. Reg. 19,638 (Apr. 29, 2009) (to be codified at 30 C.F.R. pts. 250, 285, 290); see also U.S. DEP'T OF THE INTERIOR, GUIDELINES FOR THE MINERALS MANAGEMENT SERVICE RENEWABLE ENERGY FRAMEWORK (2009).

355. For a detailed discussion of the MMS final rule, see Peter J. Schaumberg \& Angela F. Colamaria, Siting Renewable Energy Projects on the Outer Continental Shelf: Spin, Baby, Spin! 14 ROGER WILLIAMS UNIV. L. REV. 624 (2009). 
own federally approved coastal zone management plan (CZMP). ${ }^{356}$ Rather than taking the form of a single document, the Florida plan is a "network of 24 statutes administered by nine state agencies and five water management districts." 357 To date, none of the statutes sets out policies specifically for siting offshore wind or ocean current facilities. This is problematic, given that in order "to maximize the opportunity afforded the state by the CZMA consistency requirement," Florida's own CZMP must "address proposals for wind [and ocean] energy projects proposed to be sited in state coastal and ocean waters." 358 With its own framework for offshore energy, the state could influence offshore projects in federal waters much more precisely than with existing CZMA policies because "state requirements applicable to such projects form the policies with which federal projects also must be consistent." 359 Many coastal states are already beginning to develop state policies for offshore renewable energy development, and although states "vary tremendously in their readiness to differ with federal agency decisions" under the CZMA ${ }^{360}$ Florida is behind other states in terms of preparation. ${ }^{361}$ Now is the time to carefully consider and attempt to reconcile the range of state interests that could be affected by offshore energy projects in federal water, from its coastal and aquatic preserves, to beach tourism, to fisheries. With these interests in mind, the state should determine if changes to existing statutes, or a new offshore renewable energy siting statute, are needed to ensure that federal consistency review for the CZMA provides maximum protection for state resources. ${ }^{362}$

Submerged transmission cables crossing through Florida waters and sovereign submerged lands bring the state back into the jurisdictional

356. See 16 U.S.C. $\$ 1456$ (c)(1)(A), (C); 15 C.F.R. § 930.35; see also 15 C.F.R. § 930.11(h) (defining "enforceable policy"); FLA. STAT. § 380.23 (2009) (federal consistency).

357. Federal Consistency in Florida, FLA. DEP'T ENVTL. PROT., http://www.dep.state.fl. us/cmp/federal/index.htm (last visited Oct. 10, 2010). For a complete list of the statutes, see 24 Florida Statutes of the Florida Coastal Management Program, Fla. DeP'T ENVTL. Prot., http://www.dep.state.fl.us/cmp/federal/23_statutes.htm (last visited Dec. 6, 2009).

358. Joseph J. Kalo \& Lisa C. Schiavinato, Wind Over North Carolina Waters: The State's Preparedness to Address Off-Shore Water-Based Wind Energy Projects, 87 N.C. L. REv. 1819, 1824-25 (2009).

359. Id. at 1825 .

360. Megan Higgins, Is Marine Renewable Energy a Viable Industry in the United States? Lessons Learned from the 7th Marine Law Symposium, 14 ROGER WILLIAMS UNIV. L. REV. 562, 575 (2009); see also id. at 579-583 (discussing emergent state level marine special planning with respect to wind projects).

361. See U.S. OfFShore Wind Collaborative, Status of U.S. OfFShore Wind DEVELOPMENT ACTIVITY BY STATE (2008), available at http://www.usowc. org/odfs/Stateoffshorewind.pdf (finding no activity in Florida, but finding activity in nearly every other East Coast state).

362. For a helpful overview of the range of issues that might be examined, see Kalo \& Schiavinato, supra note 358, at 1835-46 (2009) (relating the CZMA consistency requirement and the new MMS rule in the context of North Carolina). 
picture, as do associated facilities onshore. It is not clear, however, just how this jurisdiction will be asserted under existing law or what regulatory framework would apply to such lines. For instance, the Transmission Line Siting Act (TLSA) applies to transmission lines at least fifteen miles in length and that "cross a county line," a criterion that would arguably not be satisfied simply by means of crossing from state submerged lands onto shore. Even if the TLSA were amended to clarify its application to offshore transmission in state waters, the TLSA review is not an adequate substitute for state participation in federal siting of offshore energy projects through a CZMP that addresses offshore wind and ocean energy comprehensively.

The experience of coastal states already addressing offshore wind facilities shows that siting and permitting can be lengthy, complicated, and contentious. ${ }^{363}$ Florida should expect no less of proposals that could affect some of its most populous and tourism-dependent communities. Clear, enforceable state policies should be developed to guide implementation of the new federal rule off Florida's coasts and to balance competing coastal uses with the state's need for renewable energy.

\section{CONCLUSION}

Florida is well-positioned to dramatically alter the composition of its power supply by drawing increasingly from renewable resources for new electricity demand. A renewable portfolio standard, adopted in draft by the PSC, awaits adoption by the Legislature. Florida has access to significant renewable energy, with two of its most promising resources, solar and biomass, already being developed in the state. Rapid innovation and technological advancement in this arena will only make harnessing renewable energy more feasible.

Will this shift toward renewable energy dramatically alter the Florida landscape in the process? With careful planning, the impact from siting these new facilities can be minimized, but haphazard siting could lead to wasteful land consumption. First and foremost, Florida needs aggressive energy efficiency policies to reduce demand and the corresponding need for new facilities. Second, opportunities exist at the state and local level to guide renewable energy siting to locations that work for communities and protect natural areas. This would be a significant change from the utility-driven siting of power plants that has been the default policy in the

363. See Iva Ziza, Note, Siting of Renewable Energy Facilities and Adversarial Legalism: Lessons from Cape Cod, 42 NEW. ENG. L. REV. 591 (2008) (discussing at length the approval process and litigation surrounding the Cape Wind Energy Project off of Cape Cod, Massachusetts); Kalo \& Schiavinato, supra note 358, at 1826-32 (2009) (providing overviews of projects in Massachusetts, New Jersey, and Rhode Island). 
state for so many years. In the effort to achieve energy sustainability from renewable resources, land use sustainability should be the guiding principle for siting renewable energy projects.

We welcome responses to this Article. If you are interested in submitting a response for our online companion journal, Ecology Law Currents, please contact ecologylawcurrents@ boalt.org. Responses to articles may be viewed at our website, http://www.boalt.org/elq. 
